\title{
ABATTOIR SURVEY OF ACQUIRED REPRODUCTIVE ABNORMALITIES IN EWES IN EGYPT
}

\author{
Abou-Rawash A.A ${ }^{1}$, Elsawak $^{2}$ A.A.; Abdo W.S. ${ }^{2}$ \\ ${ }^{1}$ Pathology Dept., Fac. Vet. Med. Alex. University, Damanhour Br. \\ ${ }^{2}$ Pathology Dept., Fac. Vet. Med. Kafrelsheikh. University.
}

\begin{abstract}
A total of 300 genital tracts of adult female sheep were obtained from Kafr-Elshiekh, El-Mahala and El-Basatein abattoirs. 112 cases(37.33\%) showed lesions. Combinations of lesions in the examined genital tracts were more frequently seen than single lesions. The uterus was the most affected (27.3\%) followed by the ovary (23\%). Ovarian lesions were associated with 55 cases of uterine lesions followed by fallopian tube lesions in were found in 33 ewes $(11 \%)$ and then cervical lesions in 22 ewes(7.3\%) were present. Ovarian abnormalities were ovariobursal adhesions(11\%), cystic ovaries(5\%), oophoritis (2\%). The fallopian tubes abnormalities were(12\%), adhesions (4.3\%), salpingitis (3\%), cystic fallopian tube (1.66\%), hydrosalpinx (1\%), pyosalpinx (0.66\%), fallopian tubes occlusion(0.33\%), squmous metaplasia (0.33\%), and pachsalpinx $(0.66 \%)$.The uterine abnormalities were usually associated with ovarian lesions. The most common uterine lesions were cystic endometrial hyperplasia found in 9\% followed by endometritis in 8.3\%. Catarrhal endometritis was the most common type of uterine inflammation followed by suppurative and least common was the granulomatous inflammation. Incidence of cervical lesions were the lowest and mostly were inflammatory lesions. Well differentiated squamous cell carcinoma was also recorded for the first time in ewe.
\end{abstract}


The result of this investigation documents well the finding of high incidence of genital tract infections in the Egyptian ewes. The data also documents the prevalence of high incidence of uterine abnormalities including hydro/mucometra, endometritis and pyometra in ewes with abnormal ovarian conditions than in those with normal ovaries, which indicates a direct strong association between uterine and ovarian abnormalities. Moreover the present study indicate that acquired genital tract abnormalities in Egyptian ewes is of complex combination between infectious, managemental and nutritional causes.

\section{INTRODUCTION}

Reproductive abnormalities cause major losses of sheep production. In Egypt, most ewes are slaughtered due to infertility, the incidence of infertility in ewes reaches $20 \%$ according to the recent study of Animal Reproduction Research Institute (Esawy, 2007).

Investigation of ovine reproductive abnormalities based on a survey of abattoir specimens provides a great deal of information on prevalence of reproductive disorders and their incidence (Al-Dahash and David, 1977). Data from such a study will be conclusive and useful as it represent reflection of management conditions in sheep rearing. It would also be more realistic if it involved more than one abattoir where different age groups or parity of ewes were sacrificed.

The present work was planned to study the incidence of reproductive tract abnormalities in such ewes by gross and microscopic examinations. Abattoir materials were used to determine the extent of reproductive wastage disorders of ewes and their incidence in Egypt. 


\section{MATERIAL AND METHODS}

\section{Samples collection:}

The genital tract of three hundred ewes more than 3 years old were examined macroscopically and microscopically for different lesions in ovaries, fallopian tubes, uteri and cervices. The ewes were slaughtered in different abattoirs of Kafr El-Sheikh, El-Bastein and El-Mahala during a period between December 2005 to December 2006.

\section{Samples examination:}

The collected samples were examined macroscopically for the presence of any gross lesions. For examination of the endometrium, longitudinal section along the uterine horn extending from the uterotubal junction to the cervix was made. The ovaries were examined for congenital abnormalities, inflammatory signs, cysts in or out of the ovaries, ovarian bursal adhesions, ovarian tags and tumors., also size of the cysts measured by a scale. The fallopian tubes examined for occlusion, signs of inflammation, and distension. The uteri were examined for inflammatory signs, cysts, hydrometra, pyometra, melanosis, macerated and mummified feti and uterine neoplasms. The cervix examined for signs of inflammation, cysts and any abnormal gross structures.

\section{Histopathological examination:}

Specimens $(5 \mathrm{~cm}$ thickness) were collected from different parts of the genitalia then immediately fixed in $10 \%$ neutral buffered formalin for at least 48 hours. 
Specimens were dehydrated in alcohol, cleared in xylol and embedded in paraffin. Sections of 4 microns thick were obtained and then stained with the following stains according to Bancroft and Stevens, ( 1996).

1- Hematoxylin and Eosin (H \& E)

2- Prussian blue reaction for detection of Haemosidrin pigment.

3- Fontana stain for detection of melanin pigment.

4- Van Gieson's stain for differentiation between muscle and connective tissue.

5- Masson's Trichrome stain for collagen fibers.

6- Verhoff's stain for elastic fibers.

7- Ziehl Neelsen stain for detection of acid and alcohol fast bacilli in granulomatous lesions. After staining, tissue sections were mounted and covered with cover slides to be examined under light microscope.

\section{RESULTS}

The results of the present study revealed that 112 ewes out of 300 $(37.33 \%$.) examined tracts showed lesions. $29 \%$ showed multiple lesions and $8 \%$ showed single lesion.

The uterus was the most frequently affected. Uterine lesions were found in 82 ewes(27.3\%) exhibited 106 lesions. The second most frequently affected was the ovaries 64 ewes (21.3\%) revealing 87 lesions followed by fallopian tube in 36 ewes (12\%) forming 39 lesions and cervix in 23 ewes $(7.3 \%)$ showing 27 lesions. 


\section{I - Ovary:}

Acquired ovarian lesions were found in 64 ewes representing $23 \%$ of the total examined tracts. More than one lesion could be observed in the same ovary. The macroscopical and histological examination of the ovaries and the ovarian bursa revealed high prevalence of ovariobursal adhesion which was diagnosed in 33 cases followed by 13 cases of cystic ovaries, 10 cases of persistent of corpora lutea, 2 cases of cystic reta ovari and 6 cases of oophoritis. The frequency of the acquired pathological lesions in the ovary was higher in winter and spring than summer and autumn (table 1).

\section{Oophoritis:}

Oophoritis was recorded in 6 out of 300 examined tracts representing $2 \%$. three cases were in the right side, one case in the left and two cases were bilateral oophoritis and perioophoritis. No apparent gross changes were detected in four cases. One of the two remaining cases showed distribution of nodules of variable size on the ovary and mesovarium with ovariobursal adhesion. Cut section of the nodules showed central calcification. This case was associated with macerated fetus and presence of bony structure in the uterine lumen (Fig. 1). The other case was associated with pyosalpnix and massive ovariobursal adhesions.

Microsocpical examination of the four cases without gross changes showed infiltration of lymphocytes, plasma cells and macrophages (Fig. 2 a). Follicular atresia with increase in stromal cells and infiltration of oval cells containing brownish pigment were also detected(Fig. 2b).

The grossly observed nodules were typical encapsulated multiple granulomas formed of central area of necrosis with calcification 
surrounded by epitheloid cells, macrophages, lymphocytes and few Langhan's giant cells and encircled by connective tissue capsule, resembled to a great extent the feature of tuberculous granuloma (Fig. $2 \mathrm{c}, \mathrm{d})$. Heavy perivascular infiltration of eosinophiles was also detected.

The remaining case showed massive fibroplasia, follicular atresia and lympho-plasmcytic infiltration and stromal hyperplasia. (Fig. 3 a,b).

\section{Lesion related to cyclic changes:}

Follicular atresia encountered in many ovaries examined associated with oophoritis, cystic ovaries, ovariobursal adhesions and also with uterine affection. Follicular atresia were the predominant criteria in most of the examined ovaries.

\section{Microscopic features:}

Follicular atresia was observed in both small and large follicles. The small atretic follicles were characterized by complete absence of the ovum and its zona pellucida leaving the follicular antrum filled with homogenous eosinophilic fluid surrounded by granulosa cells which showed nuclear pyknosis and sometimes desquamation. The large atretic follicles (large form of atresia) showed degeneration and pyknosis of the ovum with enfolding of the granulosa cells which suffered from pyknosis and chromatolysis with thickening of theca cell layer and presence of thick fibrous connective tissue.

\section{Cystic ovary:}

Follicular cysts, cystic corpora lutea, subserosal cysts and cystic rete ovarii were all detected. Single or multiple luteinized and non luteinized follicular cyst, in one or both ovaries were also observed. 
NonLuteinized follicular cyst:

Nonluteinized follicular cyst was observed in 5 cases representing $1.6 \%$ of the total ewes examined. Bilateral follicular cyst was found in one case while in 4 cases ( 3 on the right side and one on the left) was unilateral. Macroscopically it was single or multiple, oval or spherical and bulging from the ovarian surface, ranged from $9 \mathrm{~mm}$ to $15 \mathrm{~mm}$ in diameter (Fig. 4). Most of the cysts had semi transparent or opaque, well vascularized thin wall. Most of them were filled with gelatinous whitish yellow colored fluid.

Microscopically, the ovum and cumulus oophorus were completely absent. The granulosa cells were found in single or multiple layers. However, in most of the cysts, the granulosa cells were highly compressed and atrophied as a result of cystic dilatation of the follicles. The nuclei of granulosa cells showed pyknosis and karyorhexsis (Fig. 5). It was very difficult to differentiate the theca interna from the theca externa. The luminal content of all cysts especially the large and thick walled was homogenous, structurless and eosinophlic. Most of the growing follicles in ovaries with follicular cysts showed different stages of follicular atresia.

\section{Luteinized follicular cyst:}

Luteinized follicular cyst was found in 3 cases representing $1 \%$ of total examined ewes. It was found in the right side in 2 cases and in one case was present in the left side. The cyst was $1 \mathrm{~cm}$ in diameter. It was thick walled and opaque. The high degree of luteinization made the cyst wall more thick. The cyst didn't have ovulation papilla and the cavity of the cyst contained viscous reddish yellow or tan material mixed with Fiberillar structures. 
Microscopical examination revealed that the ovum, the basement membrane and the granulosa cell layer were identical to those observed in the non lutienized follicular cyst but lutein cells were derived from granulosa and theca cells and appeared as large polyhedral cells with large round vesicular nuclei and slightly esinophilic vacuolar cytoplasm (Fig. 6). The theca layers became thickened and indistinguishable from each other. The non luteinized granulosa cells became sometimes difficult to detected and the lumen of the cyst contained a homogenous esinophilic material. Most of the growing follicles showed atresia.

Cystic Corpus luteum was recorded in 4 cases representing 1.3\% of total examined ewes. It was found unilaterally, in 3 cases, on the right side and in one case on the left side. It was found in one pregnant ewe, in two cases with endometritis and in one case associated with pyometra. Macroscopically, the cystic Corpora lutea were spherical in shape, had an average of $1.5 \mathrm{~cm}$ in diameter with large central cavities filled with brownish coloured fluid and have ovulation papillae. The luteal tissue was yellowish grayish in colour and fleshy in consistency (Fig. 7a). Microscopically, the cellular structure was indistinguishable from normal functionally Corpus luteum. The cavity of the cysts was lined with a thick layer of connective tissue (Fig. 7b).

Subserosal cyst was recorded in only one ewe out of 300 ewes representing $0.3 \%$ of the total examined ewes and detected microscopically in form of round cysts lined by cuboidal epithelium under the serosal layer of the ovaries which showed certain degree of hyperplasia (Fig. 8a).

Cystic rete ovarii was found in 2 ewes representing $0.6 \%$ of total examined ewes and $2.28 \%$ of the ovarian lesions. The lesion appeared microscopically as large multiple cysts in rete ovarii (Fig. 8b). 
Persistent Corpus luteum was recorded in 10 cases representing $3.3 \%$ of examined ewes. Persistent Corpora lutea were present in both sides in 2 cases, in the right side in 5 cases and in the left side in 3 cases.

Macroscopically, persistent corpus luteum appeared as spherical, fleshy mass bulging over the surface of the ovary. On cut section fine connective tissue septa radiating from the center toward the periphery were observed similar to normal corpus luteum except persistent corpus lutetium was firm in consistency and dark brown in colour. Persistent Corpora lutea were associated with endometritis, pyometra, mummified fetus, ovariobursal adhesions and hydro salpnix (Fig. 9a,b,c).

Microscopically, it was identical to normal functional Corpora lutea but with thick connective tissue capsule.

Ovariobursal adhesions was recorded in 33 cases representing 11 $\%$ of total examined ewes. Ovariobursal adhesions represented the most common ovarian lesions. They were in form of ovarian tags in 20 ewes while in 13 ewes the ovary was completely encapsulated with connective tissue. The adhesion was unilateral in 28 cases. In 18 cases the adhesions was in the right side and in 10 cases in the left side while in 5 cases it was bilateral.

Macroscopically, ovarian tags were fine thin strands of connective tissue which connected the mesovarium, with mesosalpinx, and uterine tube (Fig.10a) or ovaries were completely encapsulated with fibrous connective tissue associated with cystic dilatation of fallopian tube, or completely embedded in the connective tissue of the mesovarium. The ovarian tags were usually associated with smooth inactive ovaries or with persistent corpus luteum while complete encapsulation of the ovary was associated with perioophorities, pyometra and or hydrosalpinx. 
Microscopically, massive ovariobursal adhesion with atresia of the most growing follicles was detected. Also excessive fibrous connective tissue proliferation was noticed in both the cortex and medulla which sometimes surrounded the ovarian surface. Leukocystic infiltration around the ovaries mainly lymphocytes and plasma cells was occasionally observed especially in perioophoritis.

Haemorrhagic cyst was macroscopically detected on cut section in one case, as round dark red mass, $1.5 \mathrm{~cm}$ in diameter and surrounded by the ovarian tissue (Fig. 10b ). Under the microscope the lesion appeared as a large mass of clotted blood, with haemosidrine pigment deposition and organized center surrounded with a fibrous connective tissue capsule similar to the theca layers of large follicle.

\section{II - Fallopian tube:}

Acquired fallopian tube abnormalities were identified in 36 cases out of 300 examined ewes. The recorded abnormalities were salpingitis, adhesions, cystic fallopian tube, hydrosalpinx, pyosalpinx, pachysalpinx, occlusion of fallopian tube and squamous metaplasia representing 3.3\%, $4.3 \%, 1.66 \%, 1 \%, 0.66 \%, 0.66 \%, 0.33 \%$ and $0.33 \%$ of the total examined tract respectively (table1).

Salpingitis (the inflammatory lesions in the fallopian tube) were seen in 9 cases representing $3 \%$ of the total tracts examined. This lesion was usually bilateral. The affected fallopian tubes did not show any gross signs, except in one case where nodules could be observed in the serosa.

Microscopically In acute catarrhal salpingitis there was mucosal hyperplasia with occasional degeneration, while the lamina propria was infiltrated with lymphocytes and plasma cells. Hyperplasia in some cases was accompanied with formation of microcystes in the mucosa (Fig. 
11a). In chronic catarrhal salpingitis, fibrosis was marked especially in submucosa. Atrophy of the muosal folds of the fallopian tube with infiltration of lymphocyes and heamosidrin deposition in the submucosa were also observed. In one case the serosal layer of the fallopian tube was covered with granulomatous nodules (Fig. 11b).

Ovariobursal adhesion was the most common lesion found and was identified in 13 cases out of 300 . The adhesion varied from thread like strands of fibrous tissue attached to the ovary and to the mesosalpinx to completely covering the ovary and the fallopian tube. One case of adhesion was associated with hydrosalpinx, five cases were associated with oophoritis and one case with pyosalpinx.

Hydrosalpinx was recorded in 2 cases representing $0.66 \%$ of the total examined ewes. It was characterized by the distension of the entire length of the fallopian tube from the uterotubal junction to the infundibulum. The tube contained clear and colourless watery fluid. In one case the hydrosalpinx was associated with ovariobursal and uterine adhesion and the other case was associated with pyometra Microscopically there was complete absence of the mucosal folds or presence of multilocular large cysts. The epithelium lining was preserved and rested on a thin muscle layer.

Cystic changes in the fallopian tube were identified in 5 cases representing $1.66 \%$ of the total examined ewes. Macroscopically cystic hyperplasia was characterized by enlargement of the fallopian tube with the serosal surface covered with multiple nodules. Usually it was bilateral and associating cystic ovarian disease. Microscpically it were formed of either fusion of hyperplastic mucosal folds forming mucosal cysts, or showed presence of multiple intraepithelial cysts in the infundibulum and the ampulla (Fig. 12a,b) 
Grossly, pyosalpinx was characterized by distension of the fallopian tube with pus and it were usually associated with ovariobursal adhesions and pyometra. Under the microscope it is a frank suppurative salpingitis characterized by a great thickening of the lamina propria by heavy infiltration of neutrophils, macrophages, lymphocytes and plasma cells. The epithelium lining was atrophied or desquamated. It was also accompanied with loss of the mucosal folds and cystic structures in the wall of the tube.

Pachysalpinx detected only in one case representing $0.33 \%$ of the total examined ewes. Macroscopically the fallopian tube was hard and slightly enlarged. Microscopically it was characterized by enlargement of the whole thickness of the fallopian tube by hypertrophied thick muscle layer with atrophy of mucosa and absence of mucosal folds (Fig. 12c ).

Occlusion of fallopian tube was present in one case out of 300 examined ewes. Macroscopically, the fallopian tube was dark bluish in colour. Occlusion of the tube was due to presence of a homogenous granular material in the lumen causing hardening of the occluded part and distention of the proximal part of the fallopian tube. Microscopic examination revealed presence of a homogenous eosinophilic mass filling the lumen of the tube. Calcification in the center with complete absence of the mucosal folds and desquamation of the lining epithelium of the tube with partial fusion were also detected (Fig. 12d ).

Squamous metaplasia was recorded in the right side of one case associated with pyometra. Microscopically the epithelium showed metaplasia to stratified squamous epithelium with absence of the mucosal folds (Fig. 13). 


\section{III- UTERUS:}

The acquired uterine abnormalities were various; (tab. 2) Adenomyosis, Adhesions, Uterine melanosis, Dead foeti, Hydrometra, Endometrial hyperplasia, (Cystic, Papillary, polypoid) and Endometritis (Catarrhal, Purulant and Granulomatous) were all recorded (table2).

\section{Dead foeti:}

Three macerated and two mummified fetuses were identified.

\section{Adenomyosis:}

It was found in 2 cases of showing presence of the uterine glands deep between the uterine muscle layers. One was associated with cystic endometrial hyperplasia and the other was associating endometritis.

\section{Endometritis:}

Inflammation of the uterus was recorded in 25 out of 300 examined ewes representing $8.3 \%$ of the total examined ewes. It included acute and chronic catarrhal endometritis (13 cases), acute and chronic purulant endometritis (9 cases) and granulomatous endometritis (3 cases).

\section{Catarrhal endometritis:}

Macroscopically, the uterine wall was either showing no signs particulary in mild form or it was edematous or showed peticheal serosal haemorrhage. In severe form the endometrial surface was covered with discoloured exudates. While, chronic cases showed marked thickening in the uterine wall and narrowing of the lumen.

Microscopically, mild cases showed slight desquamation of surface epithelium, congestion, and subepithelial infiltration of lymphocytes some plasma cells, and neutrophils. The lymphocytic infiltrations varied from mild to severe infiltration especially periglandularly with atrophy of some glands and severe stromal edema. In severe cases, desquamation 
of epithelium was accompanied with subepithelial diffuse necrosis and heavy inflammatory cell infiltration. In majority of cases the infiltrative change was the most prominent with predominance of lymphocytes which were densely distributed in the endometrial stroma particularly periglandular. Not infrequently the periglandular lymphocytic infiltration was so severe that it leads to cystic degeneration and necrosis of the gland. In addition, some endometrial glands showed degeneration, necrosis or atrophy, other revealed dilatation (Fig. $14 \mathrm{a} \mathrm{b} \mathrm{c} \mathrm{d).}$

In chronic endometritis together lympho-plasmocytic infiltration, periglandular fibroplasia glandular hyperplasia and atrophy were the main signs of chronicity. Fibroplasia was mainly present periglandulary and accompanied with atrophy of some glands and cystic dilatation of others. In addition, Stromal fibrosis was sometimes accompanied with endometrial gland hyperplasia forming glandular nests separated by fibrous connective tissues. Perivascular fibrosis and hyalinization of endometrial blood vessels were present in few cases together with hemsidrin pigment (Fig. 15a,b,c; 16a,b,c,d).

\section{Purulent endometritis:}

It was recorded in 9 cases out of 300 examined ewes. Five of them showed features of acute suppurative inflammation and the rest four showed chronic suppurative reaction.

Acute suppurative endometritis: Macroscopically, the uterine wall was thickened and edematous with congestion of the mucosa. The uterine contents of pus varied from few milliliters to about $20 \mathrm{ml}$. Pus was white or grayish white or in some cases creamy with offensive odour. Examination of the ovaries of five cases revealed presence of persistent Corpora lutea in 3 cases and cyclic Corpus luteum in the other 2 cases (Fig. 17). Microscopically the lumen was filled with exudate Kafrelsheikh Vet. Med. J. Vol. 6 No. 2 (2008) 
containing living and dead neutrophils with focal or diffuse desquamation of the epithelium. the endometrial epithelium showed subepithelial periglandular and intraluminal infiltration of neutrophils with diffuse periglandular oedema (Fig. 18a).

Chronic suppurative endometritis (pyometra) was recorded in 4 cases out of 300. Macroscopically, the uterus was markedly enlarged with fluctuating thin wall and slight congestion of the endometrium. The uterine lumenae contained variable amount of pus reaching to $50 \mathrm{ml}$ either creamy or caseated. Persistent Corpora lutea were present in 2 cases and one case showed cystic corpus luteum while the forth case showed oophoritis associated with ovariobursal adhesions. Microscopically, as in acute reaction The endometrial surface showed massive necrosis of epithelium with focal stratified squamous metaplasia with heavy neutrophilc and lymphocytic infiltration of lamina propria. Most of the uterine glands showed degeneration and atrophy with periglandular and intraluminal infiltration of neutrophils (Fig. 18b, 19a,b). Periglandular fibrosis and cystic dilatation of the uterine glands with extension of inflammation to the myometrium was also detected..

Three cases out of 300 showed Granulomatous endometritis in which the uterine mucosa was rough, dry, dull and covered with dark brownish exudate and characterized microscopically by presence of typical granulomatous structures consisted of macrophages and lymphocytes infiltration with central caseation with / without calcification and encapsulation. Langerhan's giant cells were detected in the periphery of some granulomes. Periglanduular fibrobalstic proliferation with mononuclear cells infiltration and glandular degeneration were also noticed.,. In one case the typical granulomatous reaction containing giant cells was also found in the mesometrium leading to granulomatous parametritis (Fig. 20, 21). 
Twenty seven out of 300 examined ewes showed endometrial hyperplasia. The three types, cystic ( 22 cases), papillary (3cases) and polypoid ( 2 cases) types were all detected. In Cystic hyperplasia, the uterus showed numerous thin walled cysts of various sizes up to $2 \mathrm{~cm}$ in diameter, contained a clear yellowish thin fluid, distributed throughout the endormetrium in both horns or beneath the caruncles (Fig. 22a). Variable amounts of milky fluid was present in the uterine cavity. Most of the cysts were recorded in the winter season or with cystic ovarian diseases. Microscopically, most of the endometrial glands were cystically dilated and protruded above the endometrial surface (Fig. 22b) and lined with flattened epithelium. The noncystic glands revealed slight hyperplasia extending deep toward the myometrium (adenomyosis). the superficial mucosal epithelium showed desquamation or in some cases showed hyperplastic changes. Papillary and polypoid hyperplastic projection into the lumen were noticed in the respective cases (Fig. 22c, 22d).

\section{Dead foeti:}

The uterus of five ewes was flabby, distended, contained chocolate coloured exudate, with congestion and oedema of the uterine wall. Clotted flakes of pus and remnants of tissue were present indicating macerated fetus (Fig. 23a). Examination of the ovaries of these animals revealed persistent corpus luteum in 2 cases and smooth inactive ovaries in the other cases.

Microscopic examination showed necrosis and desquamation and / or squamous metaplasia of the endometrial epithelium with necrotic debris and bony structures remnants in the lumen (Fig. 23b). The endometrium glands revealed severe atrophic and necrotic changes with protein rich oedema and inflammatory cell infiltration (Fig. 23c). 
Hydrometra was observed in 2 ewes from 300 examined $(0.66 \%)$. Microscopically, the uterine wall was thin, transparent with a visible network of blood vessels. The lumen contained about one liter of turbid yellow serous fluid with whitish flakes with no remnants of fetuses or fetal membranes. The caruncles were completely undetectable.

Microscopically the uterus showed desquamation of epithelial lining, degeneration with cystic dilatation of the endometrial glands and mild leukocytic infiltration in lamina propria .

Uterine melanosis was noticed in the endometrium of 45 ewes 20 of them showed presence of another lesions and 25 of them were normal.

Grossly, it was identified as patches or pin point foci on the endometrium. Microscopically, it was seen as large cells containing dark brown pigment usually under the covering epithelium sometimes it was deeply extended in the stroma of the endometrium.

\section{Adhesions:}

It was recorded in 2 out of 300 examined ewes. Macroscopically the adhesion was either between the two uterine horns or between both uterine horns and the broad ligaments. The first case was associating granulomatous oophoritis and perioophoritis and the other case was associating pyometra and perimetritis.

\section{IX- Cervix:}

Cervicitis, the inflammatory lesion of the cervix was the main acquired lesion observed in the cervix. Fourteen cases suffered from cervicitis representing $4.66 \%$ of the total tracts examined were recorded (table2). Most of them were associated with entometritis, pyometra and dead fetuses. Macroscopically, the cervix showed varying degrees of oedema, hyperemia and mucopurulent exudates especially in cases 
associating pyometra or suppurative cervicitis, in which the mucosal folds and rugae were highly edematous and thick and were partially protruding into the vaginal lumen.

Microscopically two types of the cervical inflammatory reaction were recoginized, catarrhal cervicitis in nine cases and suppurative cervicitis in five cases.

Microscopcial examination of catarrhal cervicitis revealed desqumation of the lining epithelium, cystic dilatation and goblet cells hyperplasia in the mucous glands, subepithelial infiltration of lymphocytes and plasma cells which extended deep in the lamina propria with interstitial edema and lymphangiectasia.( (Fig. 24 a,b,c). Chronic catarrhal cervicitis was characterized by atrophy of cervical glands and hyalinosis of blood vessels and submucosal fibrosis in addition to leucocytic infilteration(Fig. 24d)

suppurative cervicitis were recorded with its characteristic desquamation or squamous metaplasia of the cervical epithelium with heavy infiltration of neutrophiles (Fig. 25).

Cervical tumor was recorded in 3 cases representing $1 \%$ of the total examined tracts. Macroscopically, only one case showed gross enlargement of the cervix with absence of mucosal rugae. Microscopically, well differentiated squamous cell carcinoma consisted of nests of squamous cells extended deeply in mucosa and submucosa was detected. The tumor cells revealed moderate pleomorphism and rare mitotic figures. The tumor nests were surrounded with fibrous connective tissue and some reactive inflammatory cells (Fig. 26a, b).

Cervical hyperplasia was recorded in 4 cases out of 300 examined ewes. It was detected only microscopically revealing a papillary complex with stratified columnar epithelium at some sites. 
Abattoir Survey Of Acquired Reproductive ...

Table (1): Incidence of acquired abnormalities in ovary and fallopian tube in the examined ewes (n. 300).

\begin{tabular}{|c|c|c|c|c|c|c|c|}
\hline \multirow{2}{*}{ Criteria } & \multirow{2}{*}{ Lesion } & \multirow{2}{*}{$\begin{array}{l}\text { No. of ewes } \\
\text { affected }\end{array}$} & \multicolumn{3}{|c|}{ Location } & \multicolumn{2}{|r|}{$\%$} \\
\hline & & & Bilateral & Right & Left & total & ovarian lesions \\
\hline \multirow[t]{9}{*}{ Ovary } & Oophoritis & 6 & 2 & 3 & 1 & 2 & 6.82 \\
\hline & $\begin{array}{l}\text { Ovariobrusal } \\
\text { adhesions }\end{array}$ & 33 & 5 & 18 & 10 & 11 & 37.9 \\
\hline & Follicular cyst & 5 & 1 & 3 & 1 & 1.66 & 5.74 \\
\hline & $\begin{array}{l}\text { Luteinized follicular } \\
\text { cyst }\end{array}$ & 3 & -- & 2 & 1 & 1 & 3.44 \\
\hline & Subserosol cyst & 1 & -- & 1 & -- & 0.33 & 1.14 \\
\hline & Cystic corpus luteum & 4 & -- & 3 & 1 & 1.33 & 4.59 \\
\hline & $\begin{array}{l}\text { Persistent corpus } \\
\text { luteum }\end{array}$ & 10 & 2 & 5 & 3 & 3.33 & 11.49 \\
\hline & Cystic rete ovarii & 2 & -- & 2 & -- & 0.6 & 2.28 \\
\hline & Total & 64 & 10 & 37 & 17 & 21.3 & \\
\hline \multirow{9}{*}{$\begin{array}{c}\text { Fallopian } \\
\text { Tube }\end{array}$} & Salpengitis & 9 & 5 & 3 & 1 & 3 & 23.07 \\
\hline & Adhesion & 13 & 2 & 7 & 4 & 4.3 & 33.33 \\
\hline & Hydrosalpinex & 3 & -- & 2 & 1 & 1 & 7.69 \\
\hline & Cystic fallopian tube & 5 & 3 & 2 & -- & 1.66 & 12.82 \\
\hline & Pachysalpinx & 2 & -- & 2 & -- & 0.66 & 5.13 \\
\hline & Pyosalpinx & 2 & 1 & 1 & -- & 0.66 & 5.13 \\
\hline & $\begin{array}{l}\text { Occluded fallopian } \\
\text { tube }\end{array}$ & 1 & -- & 1 & -- & 0.33 & 2.57 \\
\hline & Squamous metaplasia & 1 & -- & 1 & -- & $\mathbf{0 . 3 3}$ & 2.57 \\
\hline & Total & 36 & 14 & 19 & 6 & 12 & \\
\hline
\end{tabular}

Table (2): Incidence of acquired abnormalities in uterus and cervix in the examined ewes (n. 300).

\begin{tabular}{|c|c|c|c|c|c|}
\hline & \multirow[b]{2}{*}{ Lesion } & \multirow{2}{*}{$\begin{array}{l}\text { Number of } \\
\text { lesions }\end{array}$} & \multicolumn{3}{|c|}{$\%$} \\
\hline & & & $\begin{array}{l}\text { Total tracts } \\
\text { examined }\end{array}$ & $\begin{array}{c}\text { Total } \\
\text { lesions }\end{array}$ & Uterine lesions \\
\hline \multirow{7}{*}{ 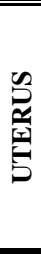 } & Cystic endometrial hyperplasia & 27 & 9 & 10.23 & 24.55 \\
\hline & Endometritis & 25 & 8.3 & 9.47 & 22.73 \\
\hline & Hydrometra & 2 & 0.66 & 0.76 & 1.81 \\
\hline & Melanosis & 45 & 15 & 17.05 & 40.91 \\
\hline & Dead feti & 5 & 1.66 & 1.89 & 4.55 \\
\hline & Adhesion & 2 & 0.66 & 0.76 & 1.81 \\
\hline & Total & 106 & & & \\
\hline \multirow{5}{*}{$\underset{\frac{1}{c}}{x}$} & Cervicitis & 14 & 4.66 & 5.06 & 59.26 \\
\hline & Cervical tumors & 3 & 1 & 1.14 & 11.11 \\
\hline & Cervical hyperplasia & 4 & 1.33 & 1.52 & 14.82 \\
\hline & Squamous metaplasia & 2 & 0.66 & 0.76 & 7.41 \\
\hline & Total & 23 & & & \\
\hline
\end{tabular}

N.B. Total number of ewes affected were 112 ewes. The uterine lesions found in 82 ewes. The total lesions were 106 lesions.

Kafrelsheikh Vet. Med. J. Vol. 6 No. 2 (2008) 


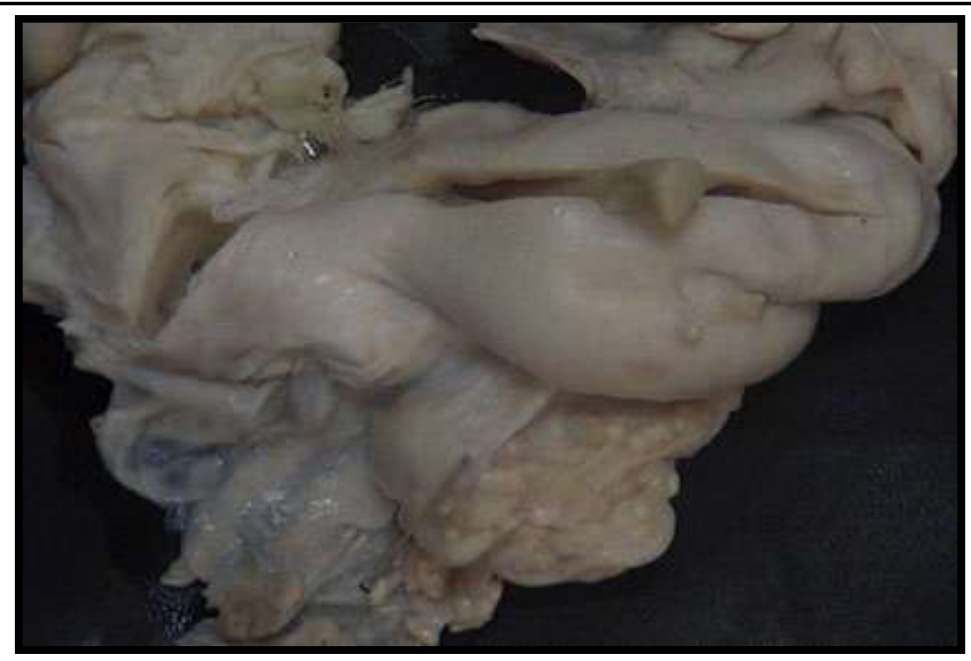

Fig. (1): Oophoritis showing disseminating nodules on the ovarian surface with ovariobursal adhesion, observe bony structures in the uterine horn.

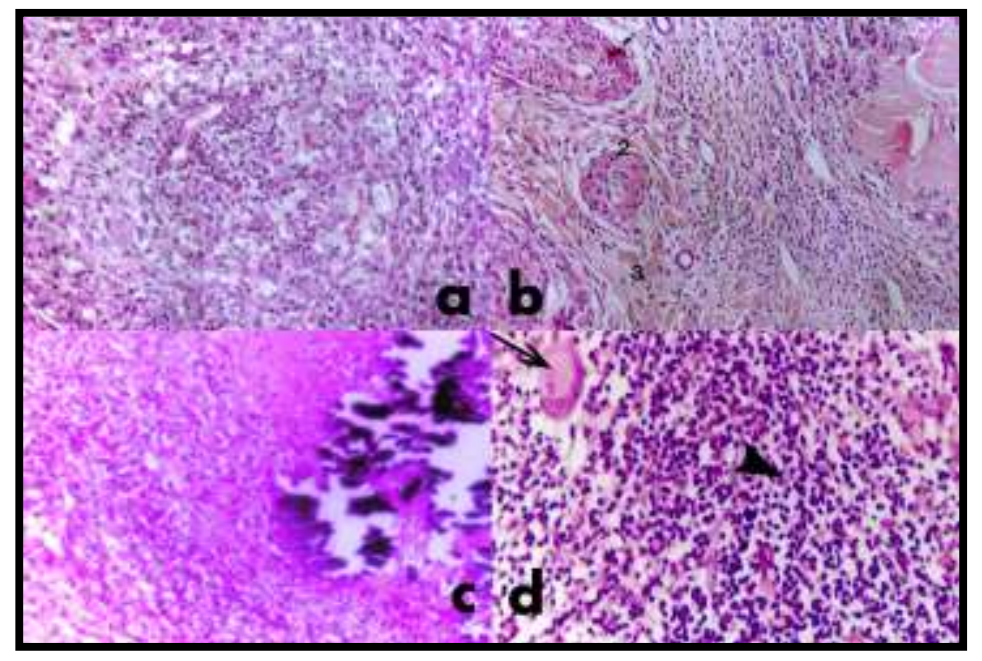

Fig. (2): Ovary showing heavy infiltration with lymphocytes (a) (H\&E)., Atresia and hyalinization of the follicles, fibroblast proliferation and infiltration of large cells containing brown pigment(b). Granulomatous oophoritis showing presence of nodular structure with central casiation and calcification (c). higher magnification of (c) peripheral infiltration of lymphocytes (arrow head) and giant cells (thin arrow) (H\&E X100, d X200). 


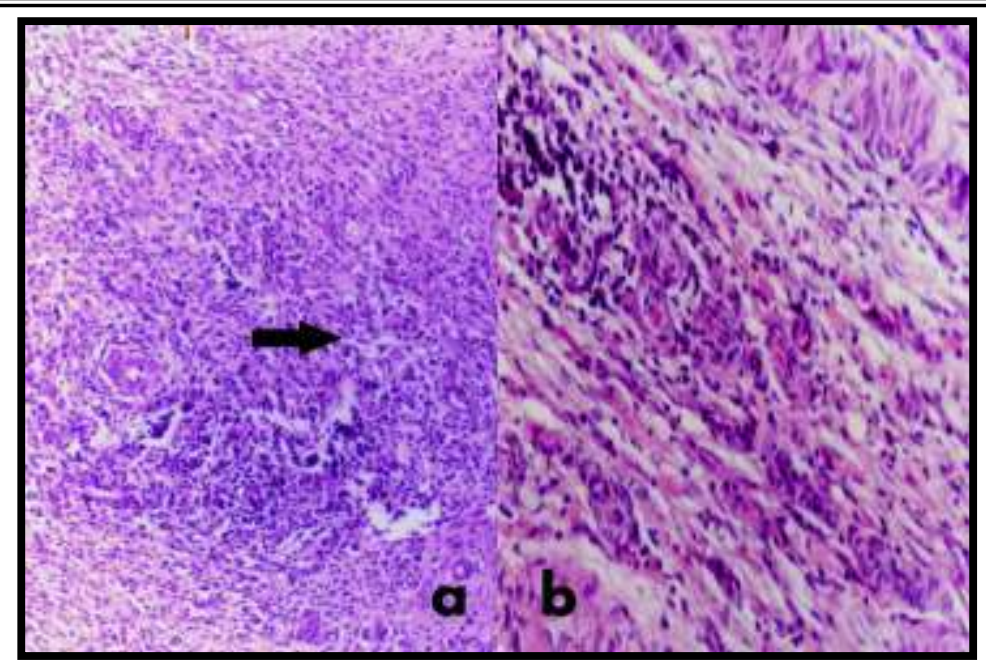

Fig. (3): (a)Oophoritis showing massive fibroplasia, infiltration of lymphocytes (thick arrow) with atresia of follicles(H\&E X100). (b)Higher magnification of (a) showing infiltration of the ovarian stroma with lymphocytes with newly formed blood capillaries(H\&E X200).

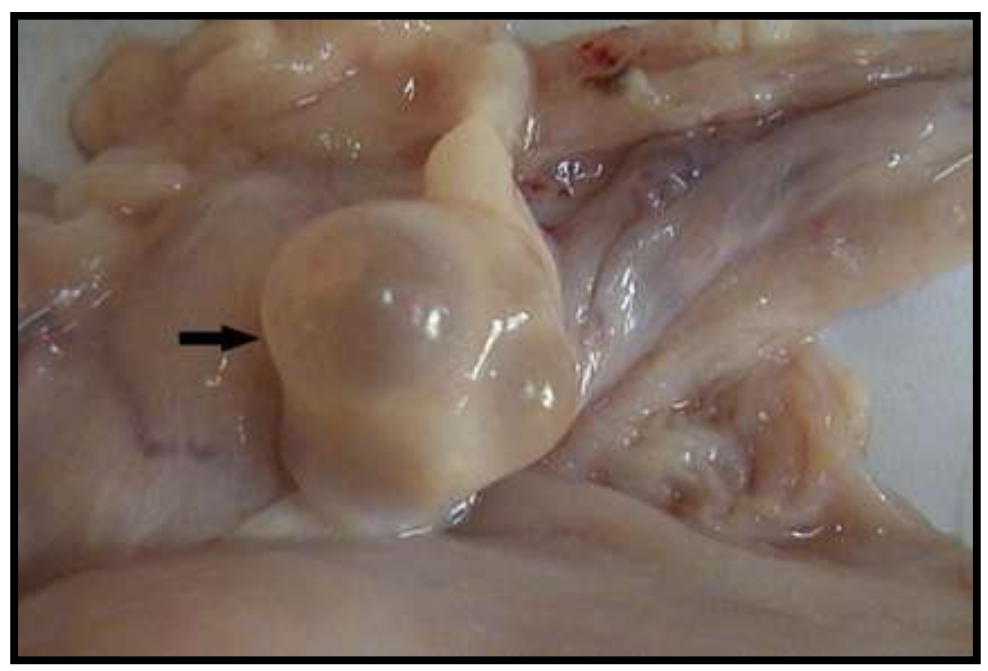

Fig. (4): Ovary showing multiple follicular cysts bulging from the surface (arrow). 


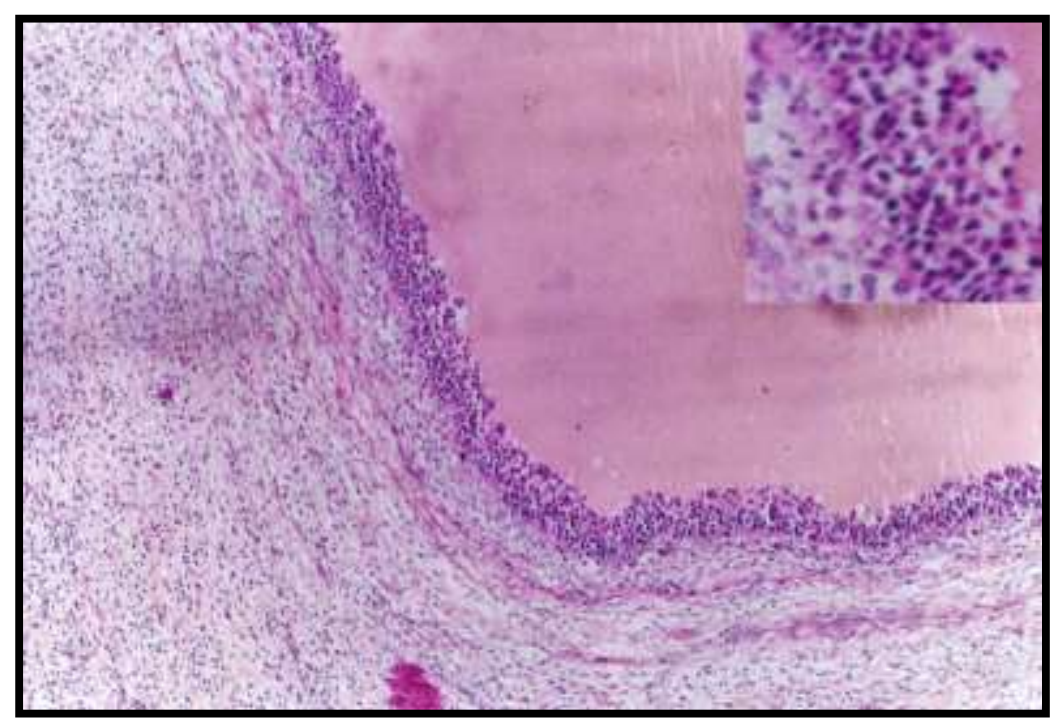

Fig. (5): Follicular cyst showing multiple layers of granulosa cells (H\&E, 10X10).

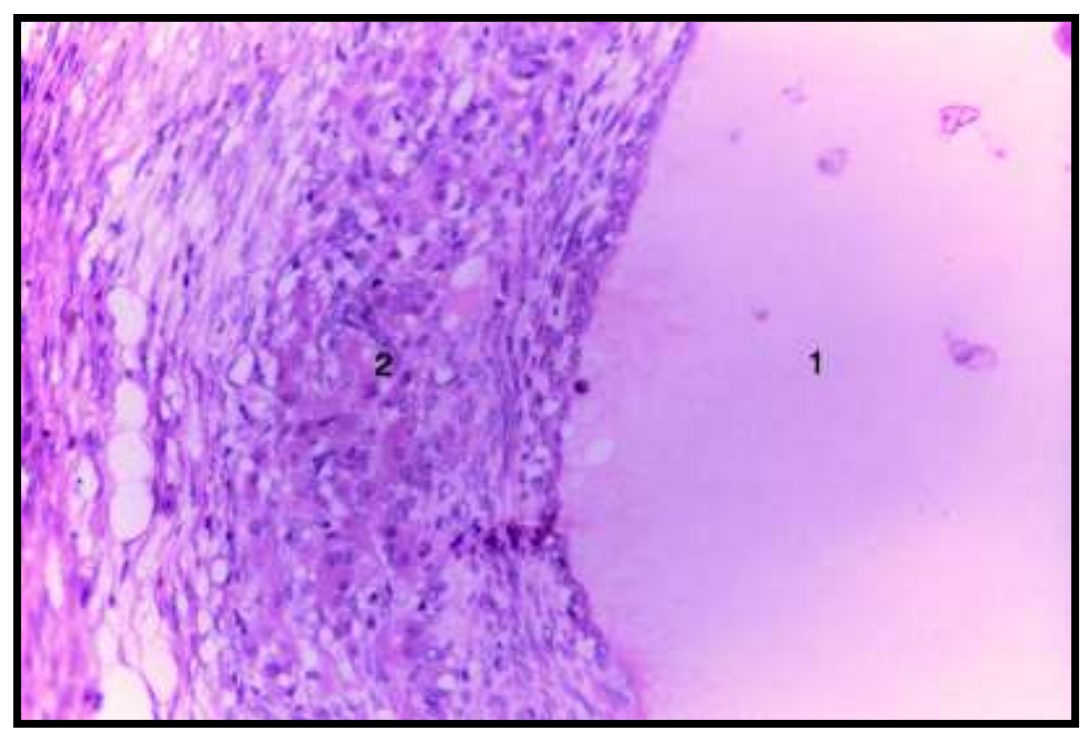

Fig. (6): luteinized follicular cyst showing luteinization of theca cells (2) and large central cavity containing homogenous esinophilic material (1) (H\&E x200). 


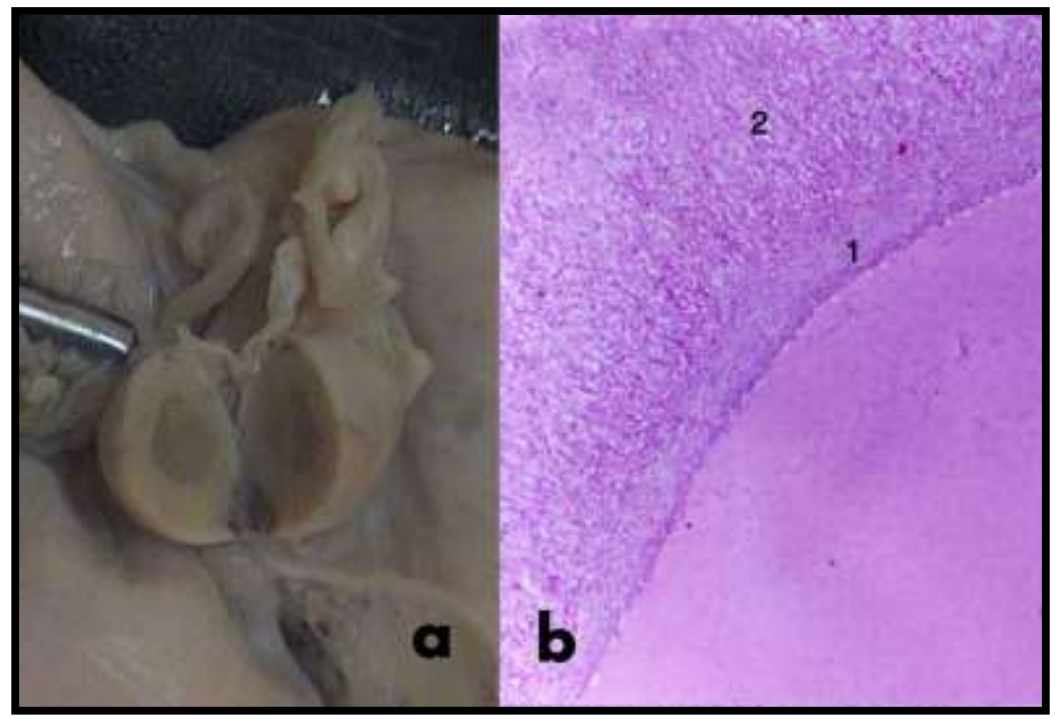

Fig. (7): (a)Ovary showing cystic corpus luteum. (b)Cystic CL, notice thick connective tissue layer1 separating theca lutein cells 2 from cavity of the cyst (H\&E, 10x10).

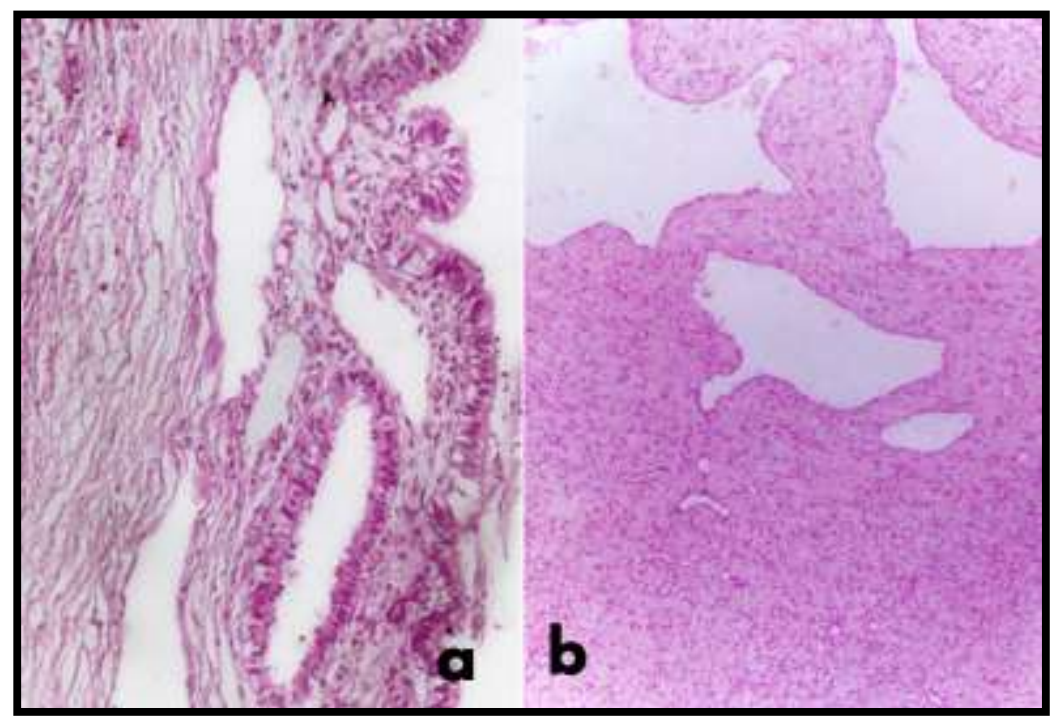

Fig. (8): (a) Ovary showing hyperplasia of the serosal surface with presence of subserosal cyst. (b) Ovary showing cystic rete ovarii (H\&E, X200, $\mathrm{X} 100$ ).

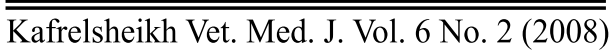




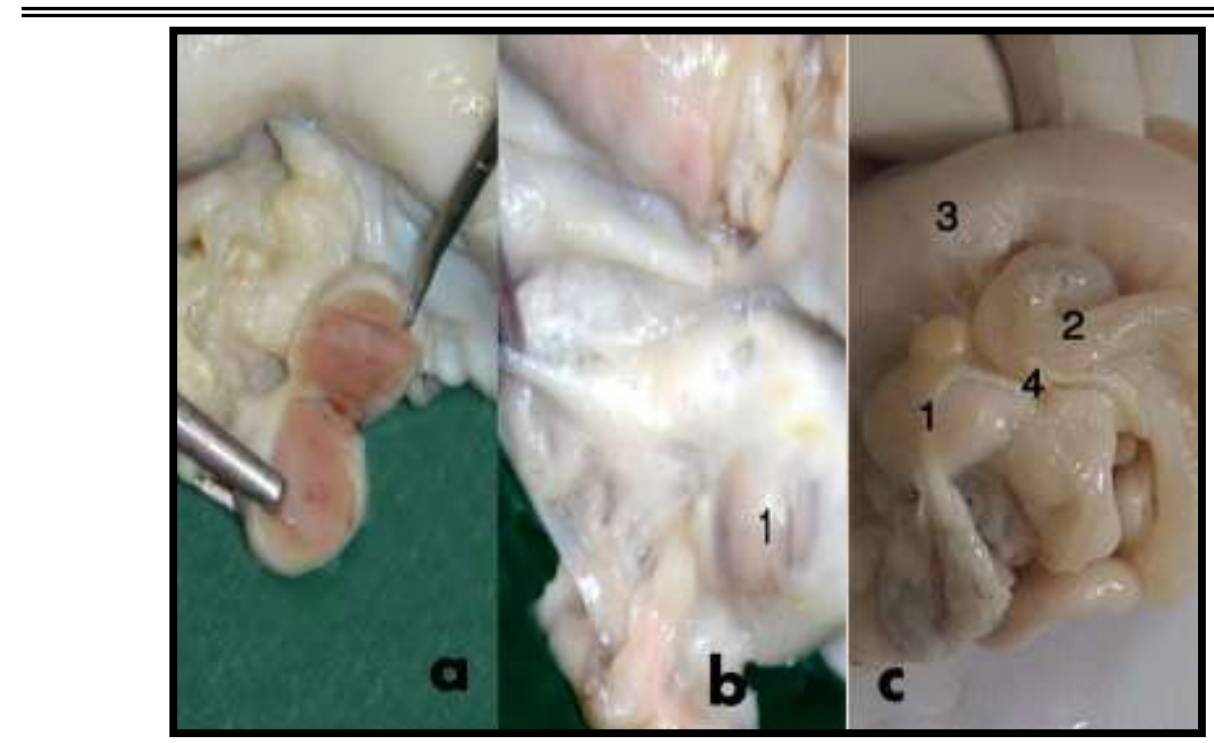

Fig. (9): Ovary showing (a)spherical, fleshy and bulging persistant corpus luteum. (b) persistent corpus luteum 1 associated with ovariobursal adhesion, (c)Persistant corpus luteum (1) associated with hydrosalpinx 2 and ovariobursal adhesion 4.3 uterus.

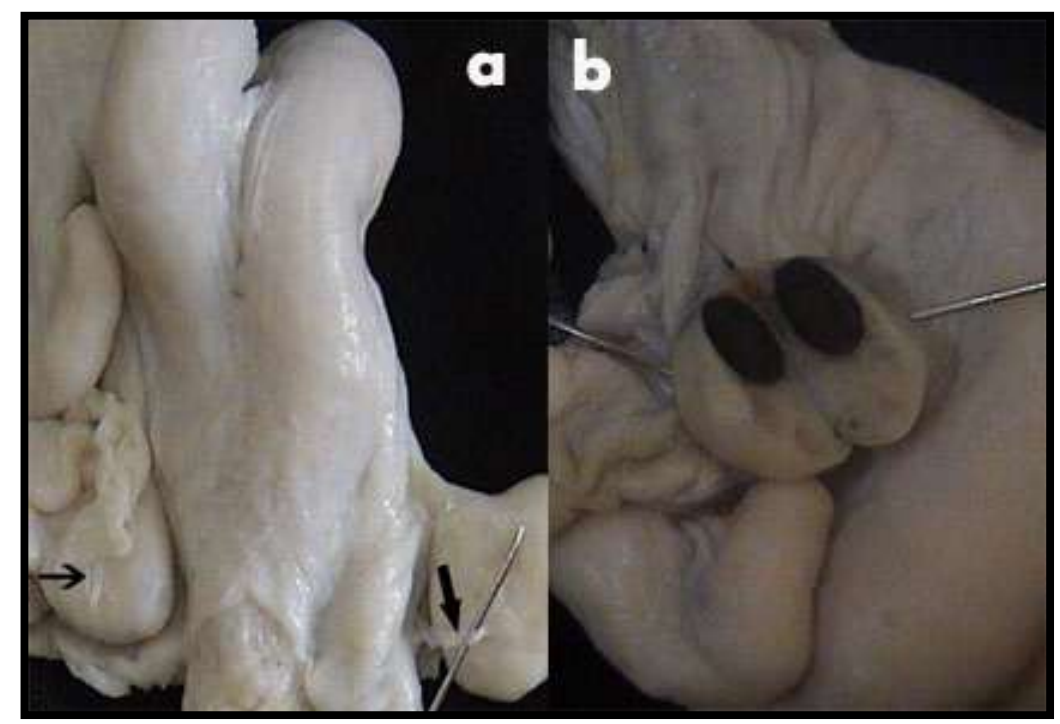

Fig. (10): (a) Ovariobursal adhesion with fibrous C.T. band in the right ovary (thick arrow), fibrous tags in the left ovary (thin arrow). (b) Ovary showing darkened haemorrhagic cyst in cut section. 


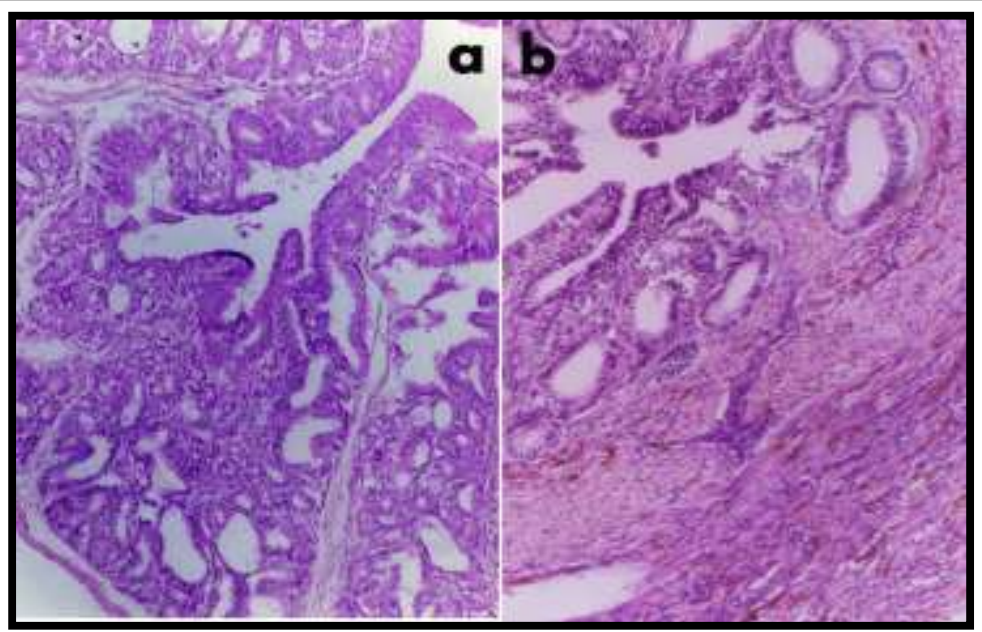

Fig. (11): (a) Acute catarrhal salpingitis, showing mucosal hyperplasia and microcysts. (b)Chronic catarrhal salpingitis notice increased fibrous connective tissue with atrophy of the mucosal folds and haemosidrosis (H\&E, X100).

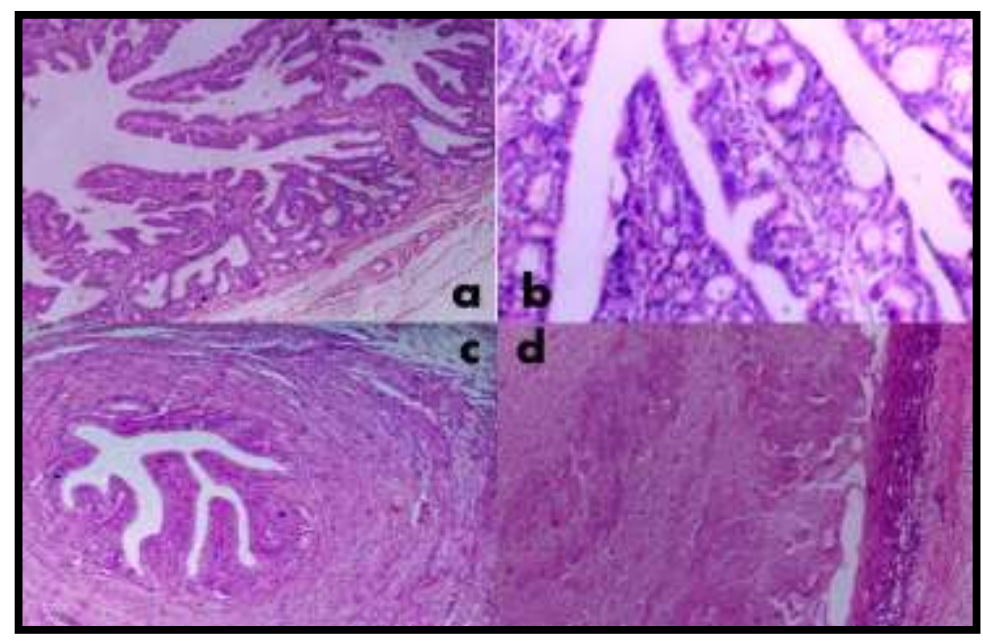

Fig. (12): Fallopian tube showing (a)hyperplasia and fusion of the mucosal folds forming mucosal cysts. (b) Multiple intraepithelial cysts. (c) Pachysalpinx, notice hypertrophy of muscle layer and decrease in the mucosal folds. (d) Occlusion with homogenous esinophilic mass (H\&E, X50). 


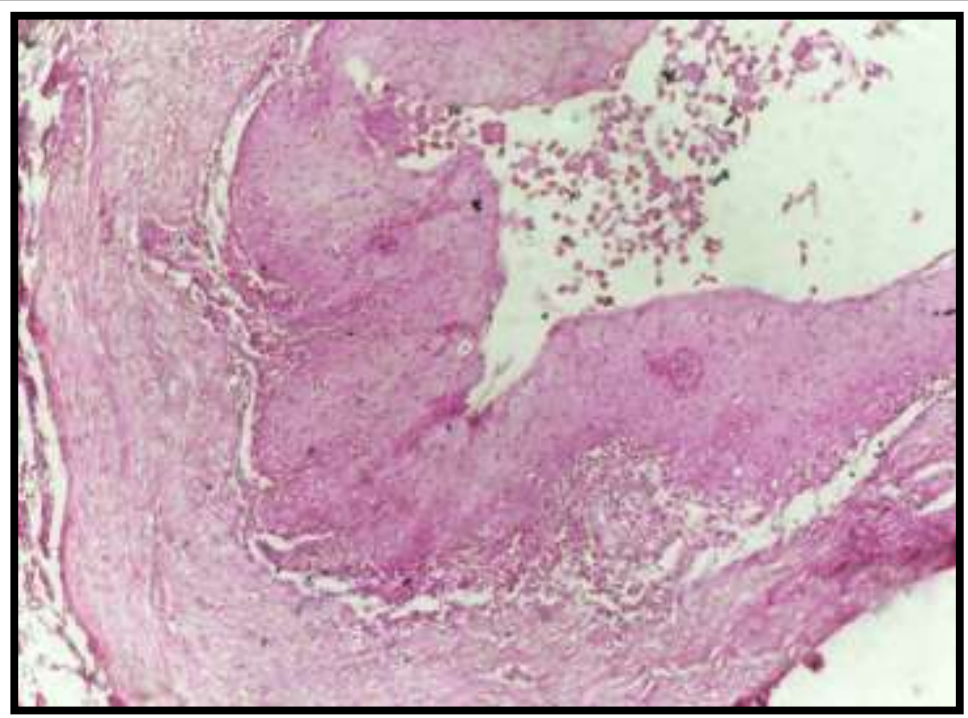

Fig. (13): Fallopian tube showing squamous metaplasia (H\&E, X100).

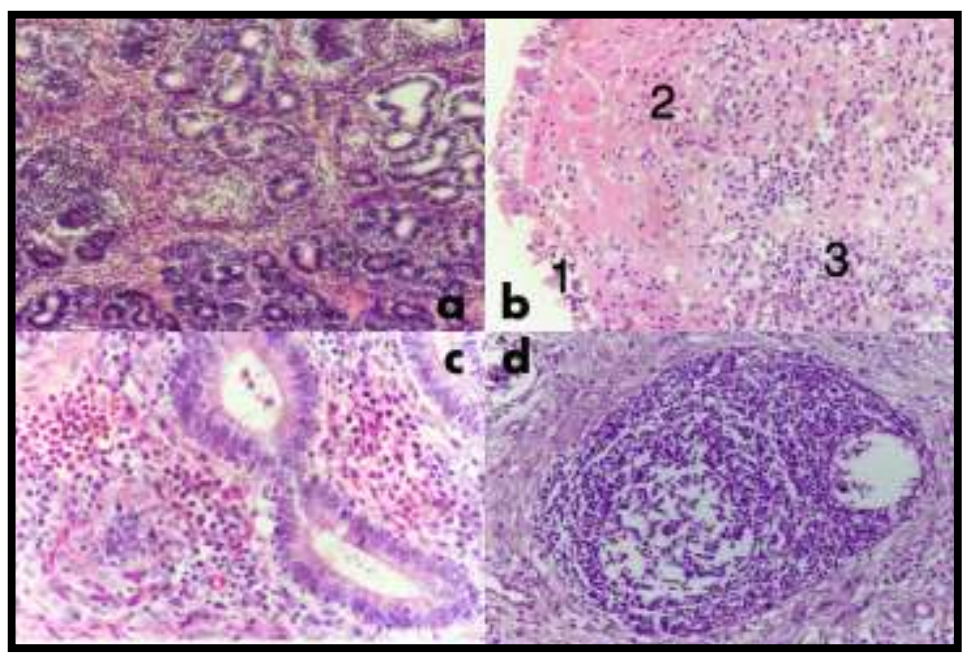

Fig. (14): Uterus showing acute catarrhal endometritis, (a) notice heavy periglandular infiltration of lymphocytes with cystic dilatation of some glands (H\&E, X100), (b) desquamation of epithelium (1), subepithelial necrosis (2) and heavy lymphocytic infiltration (3), (c)Higher magnification of (a) showing periglandular lymphocytes and plasma cells, (d)Heavy lymphocytic infiltration around degenerated glands (H\&E, X200). 


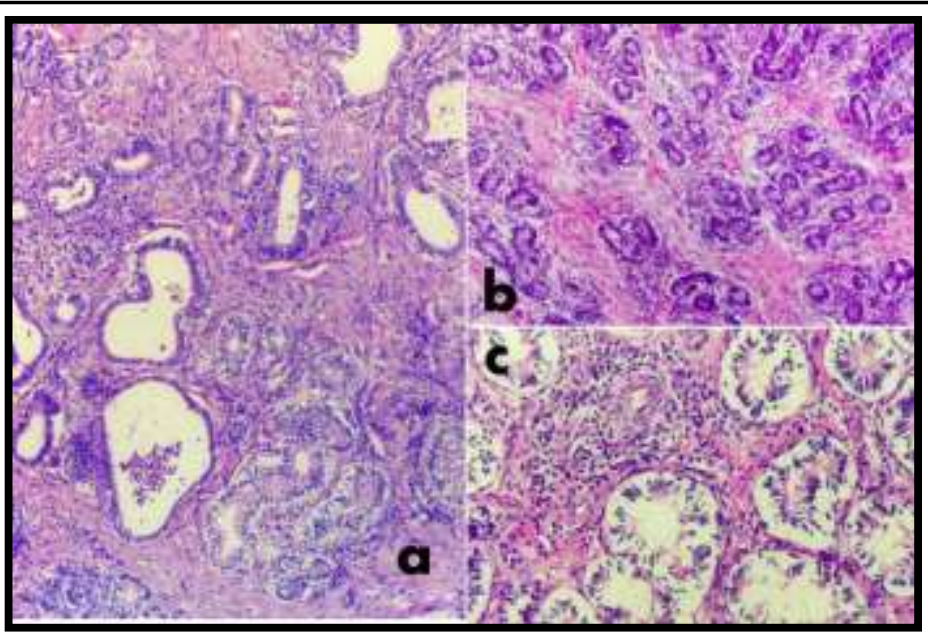

Fig. (15): Chronic catarrhal endometritis showing, (a)periglandular fibrosis associated with atrophy of the uterine glands and cystic dilatation of the other (H\&E, X100), (b) nests of glandular hyperplasia with periglandular fibrosis (H\&E, X100), (c)cystic atrophy of the uterine glands associating periglandular fibrosis (H\&E, X200).

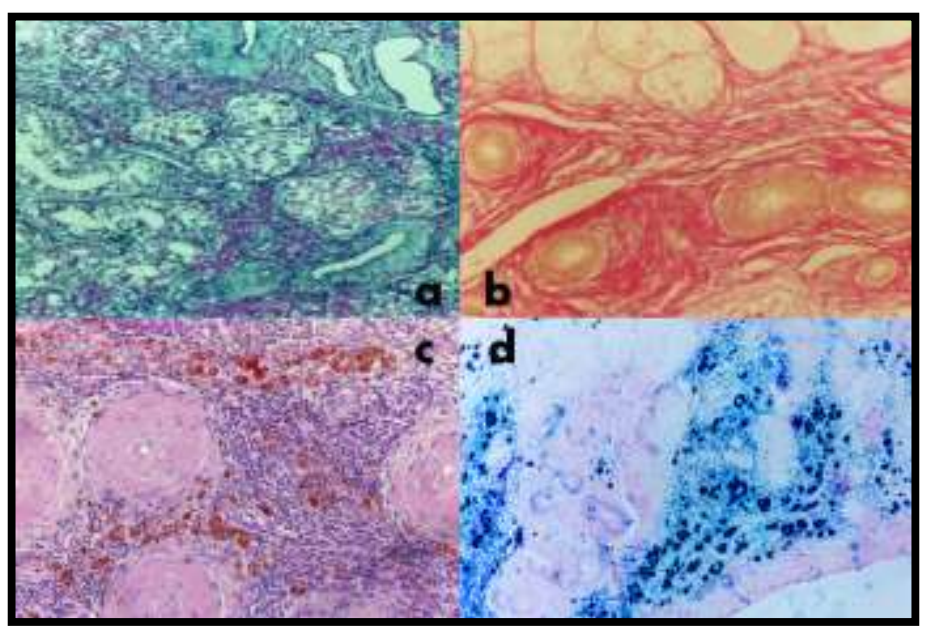

Fig. (16): Chronic catarrhal endometritis (a)showing periglandular fibrosis (Masson's Trichrome stain, X100), (b)Perivascular fibrosis (Van Gieson's stain, 10X 10), (c)Hyalinization of blood vessels and golden brown haemosidrine deposition (H\&E, X200), (d) deep blue haemosidrine deposition. (Prussian blue, 10X10). 
Abou-Rawash A.A et al.,

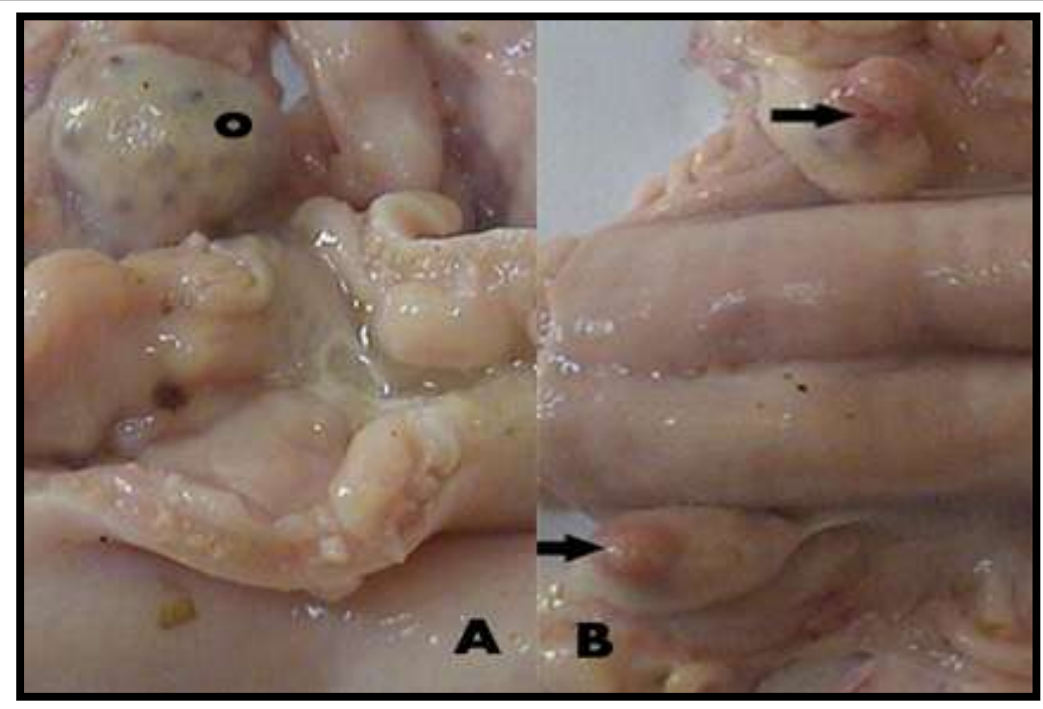

Fig. (17): Acute purulent endometritis notice (a) oedema thickening and of uterine wall and presence of pus in the uterine cavity, (b) bilateral cyclic corpus luteum (arrows).

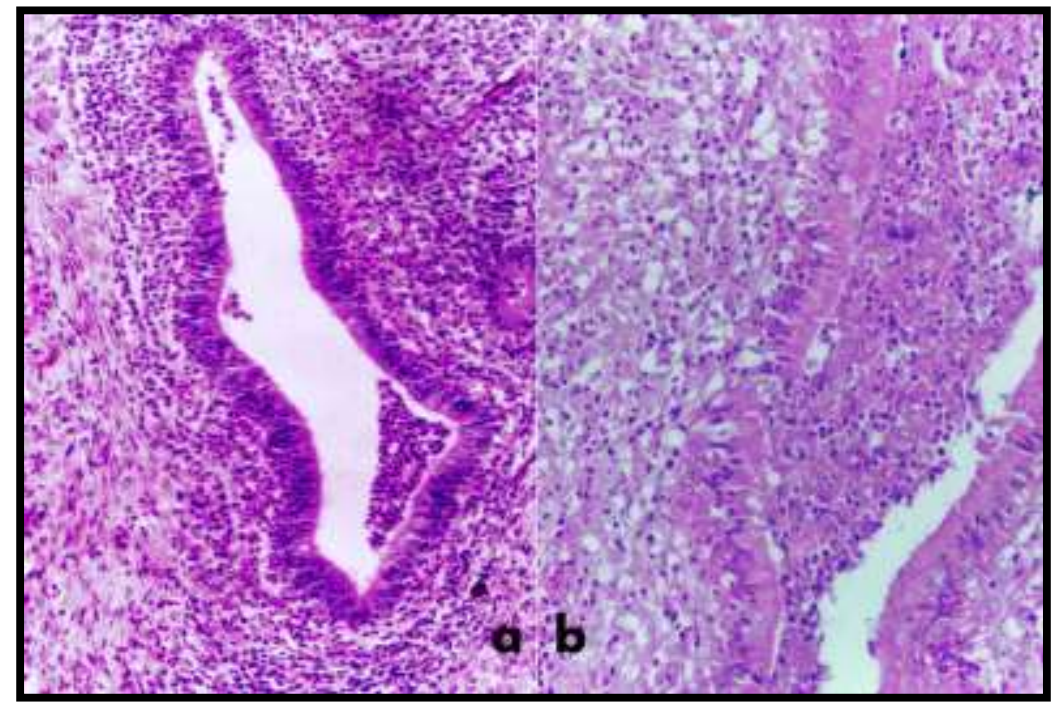

Fig. (18): (a)Acute suppurative endometritis showing intraluminal and periglandular infiltration of neutrophils (H\&E, X200), (b) Pyometra notice desquamation of epethilium and suppurative exudates in the lumen (H\&E, X 200). 


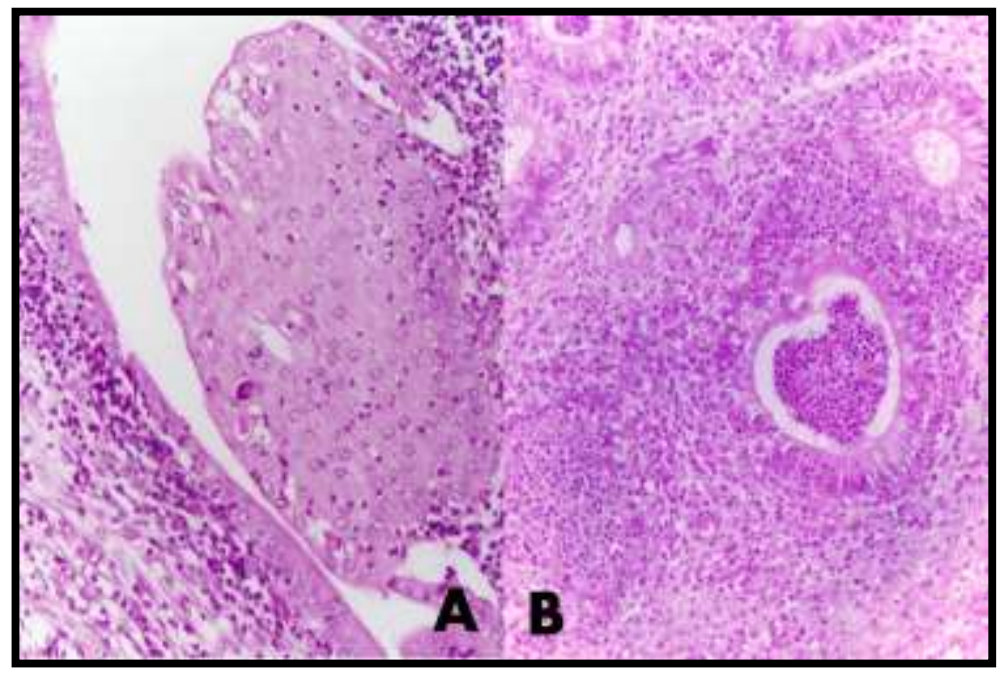

Fig. (19): Pyometra, notice (A) focal squamous metaplasia of the endometrial (H\&E, X200), (B) degeneration and necrosis of uterine glands and heavy infiltration of neutrophils (H\&E, 10X20).

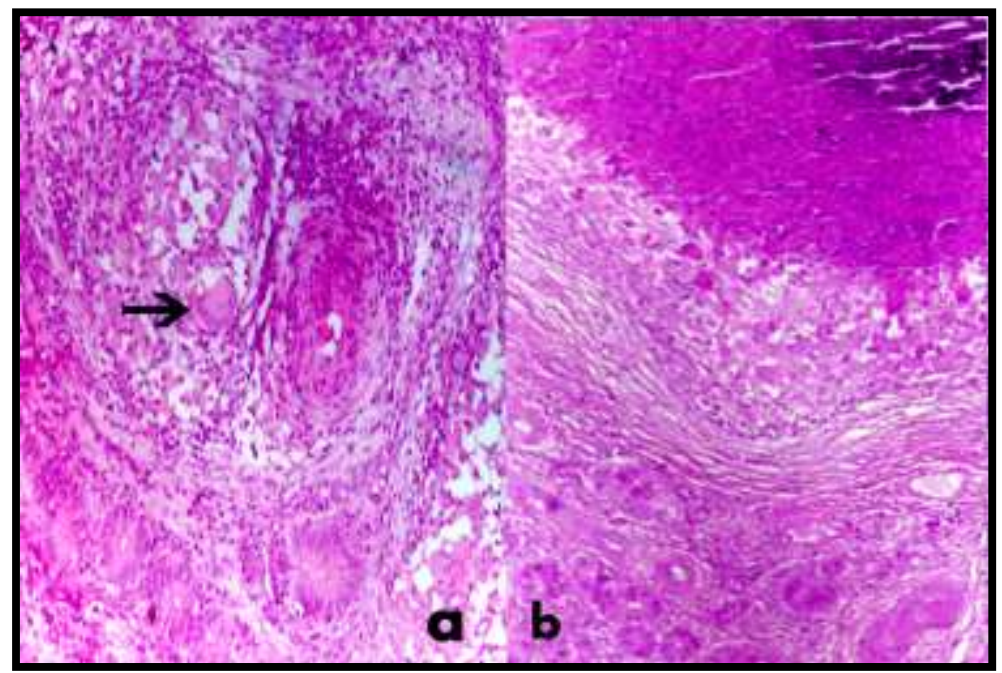

Fig. (20): Granulomatous endometritis showing (a)central caseation, lymphocytic infiltration with Langhan's giant cell (thin arrow), (b) central caseation with calcification and thick fibrous connective tissue capsule (H\&E X100).

$\overline{\text { Kafrelsheikh Vet. Med. J. Vol. } 6 \text { No. } 2 \text { (2008) }}$ 


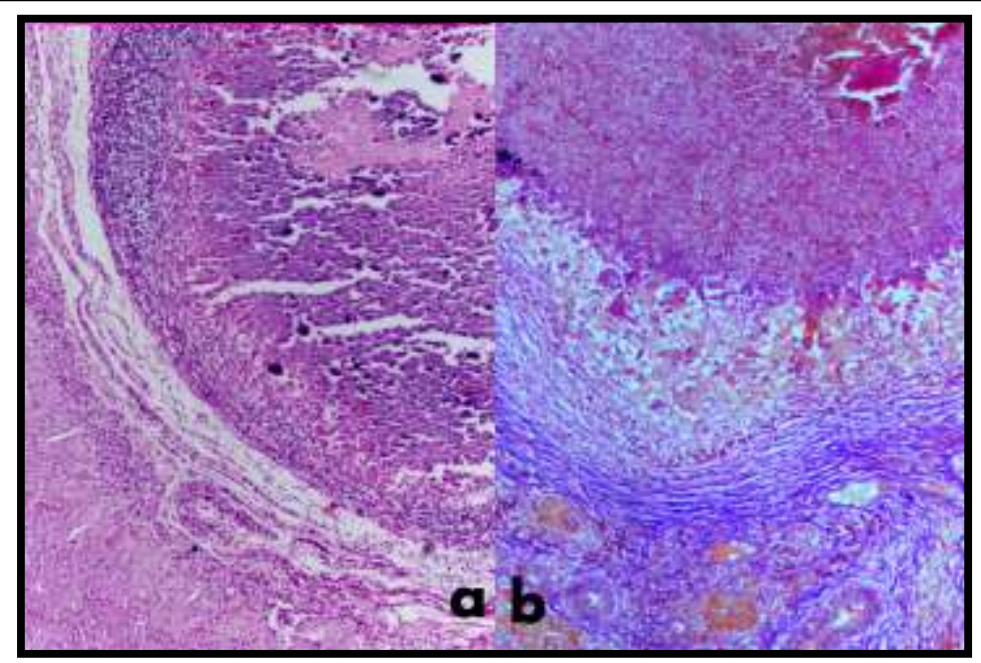

Fig. (21): (a) Granulomatous perimetritis showing central caseation and calcification, lymphocytic infiltration with CT capsule (H\&E X 100), (b)Granulomatous endometritis showing thick bluish connective tissue capsule surrounding the granulomatous structure (Massons Trichrome, 10X10).

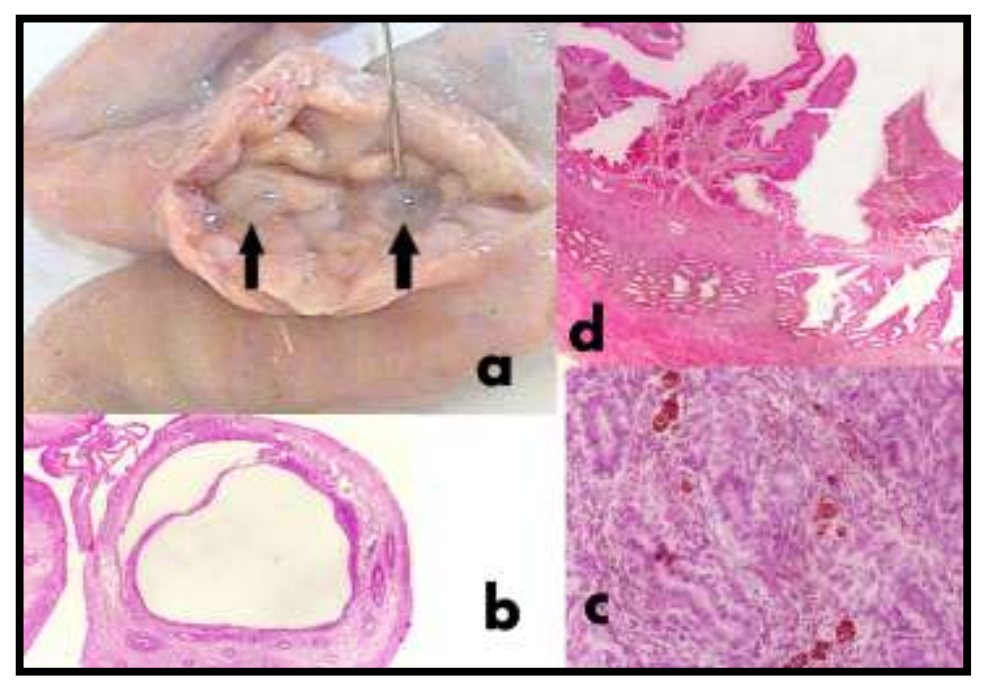

Fig. (22): Uterus showing (a)cystic hyperplasia of the endometrial (arrow), (b) papillary hyperplasia of endometrial, (c) papillary cystic hyperplasia, (d) uterine glands hyperplasia with haemosidrine deposition $(\mathrm{H} \& \mathrm{E}$, $\mathrm{X} 100$ ). 


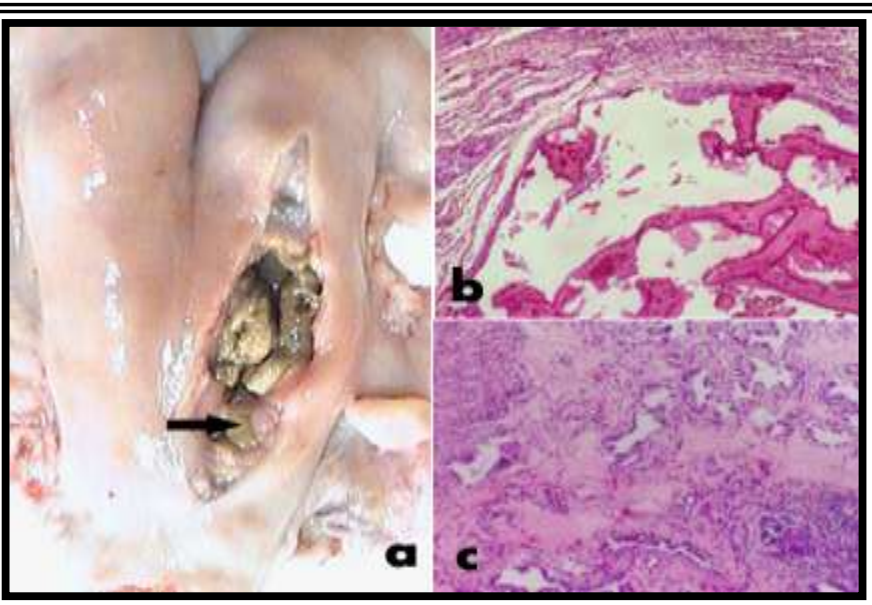

Fig. (23): Uterus showing (a) fetal remnants of macerated fetus (thich arrow), (b) structure in a distended uterine horns with atrophied endometrium, (c) severe degeneration and necrosis of uterine glands, with protein rich oedema and inflammatory cell infiltration (H\&E,X100).

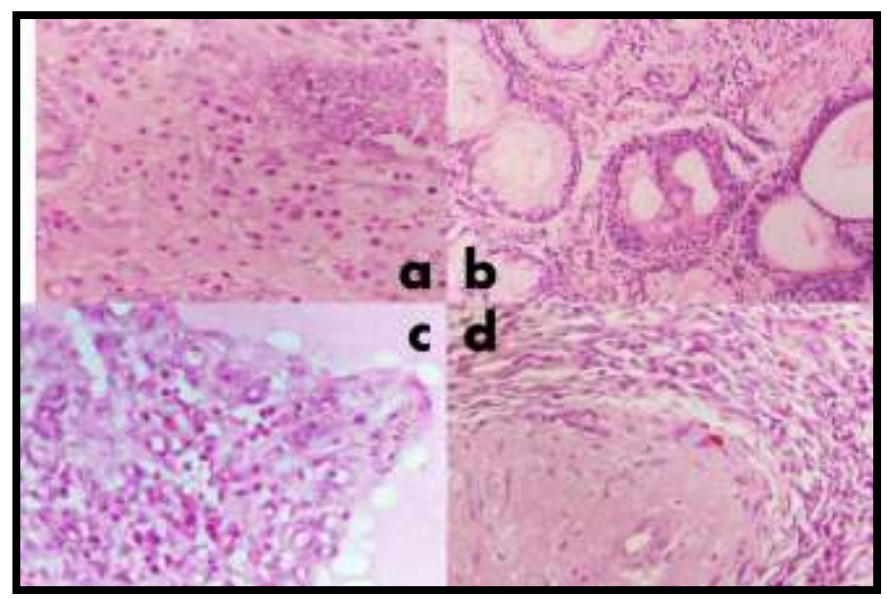

Fig. (24): Catarrhal cervicitis showing(a)desquamation of the lining epithelium with subepithelial infiltration of lymphocytes and plasma cells (H\&E, X200), (b) goblet cells hyperplasia and cystic dilation of the glands(H\&E X100), (c)edema, lymphangiectasis and lymphocyte and plasma cells infiltrations (H\&E, X100), (d) Chronic catarrhal cervicitis showing fibrosis and hyalinosis of the blood vessels $(\mathrm{H} \& \mathrm{E}$, $\mathrm{X} 100$ ). 
Abou-Rawash A.A et al.,

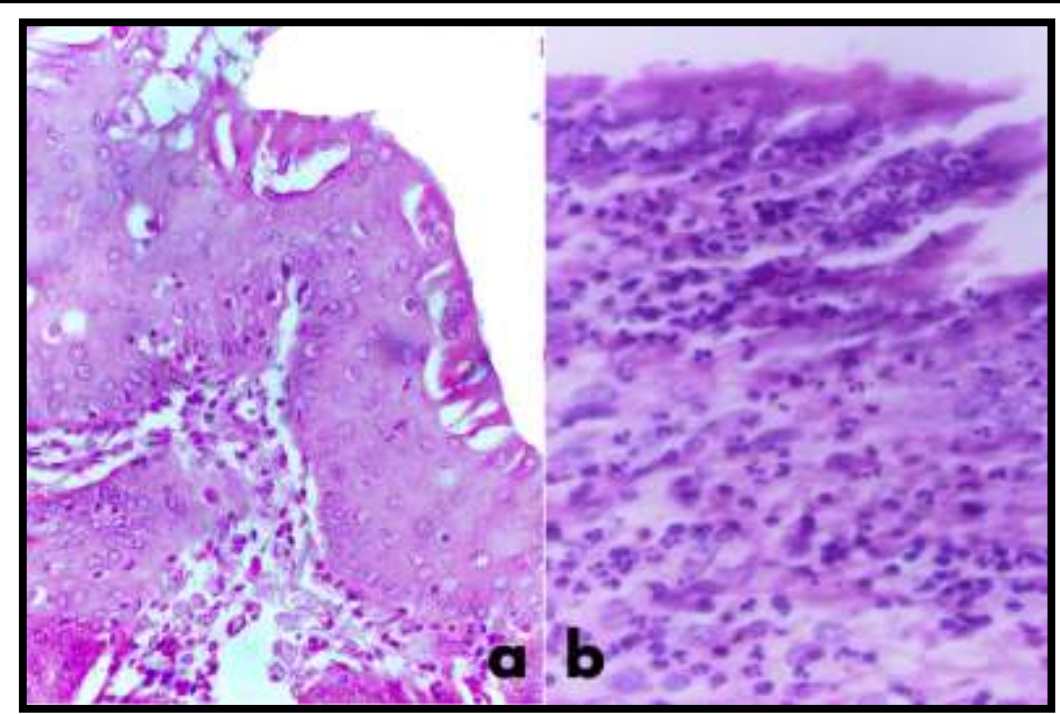

Fig. (25): Suppurative cervicitis showing (a)squamous metaplasia of the covering epithelium (H\&E, X200), (b)necrosis of the lining epithelium with diffuse neutrophilic infiltration (H\&E,X400).

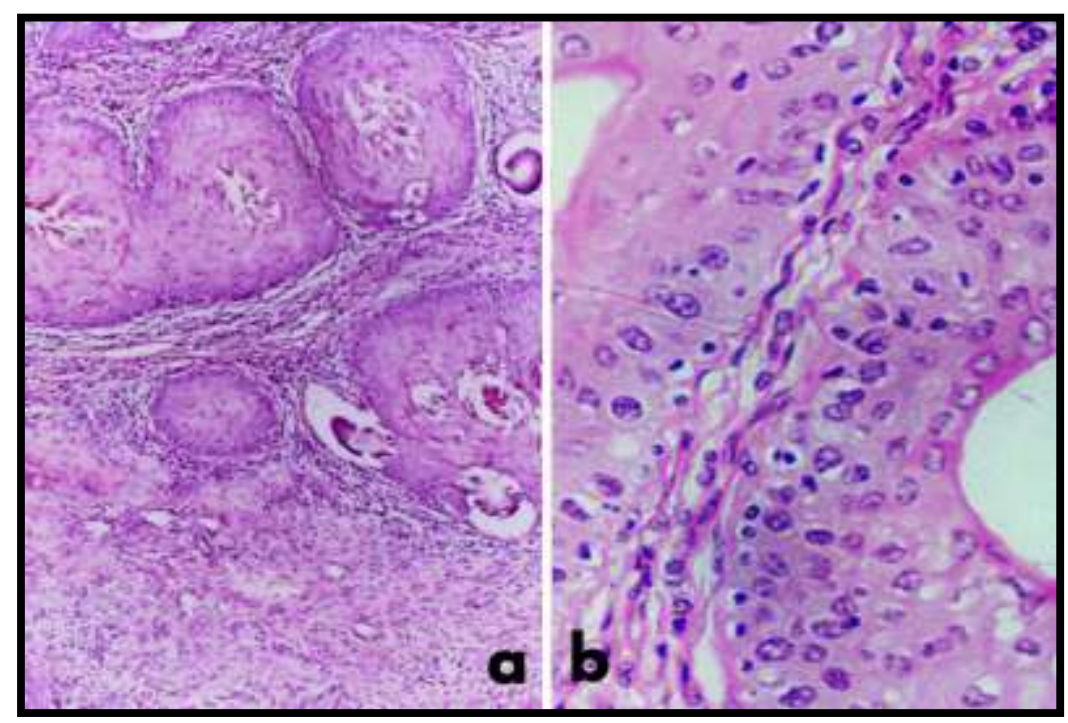

Fig. (26): Cervix showing (a) well differentiated squamous cell carcinoma notice formation of multiple cell nests (H\&E, 10X10), (b) higher magnification of (a) notice moderate pleomorphism of epithelium (H\&E, X200). 


\section{DISCUSSION}

The data obtained from this study showed the high incidence of gross reproductive abnormalities in ewes randomly chosen for slaughter. Most of these acquired lesions were, as ovarobursal adhesions, metritis and pyometra were probably due to breeding and postpartum complications. Many factors contribute to the predisposition of the reproductive tracts to infections. The natural breeding of ewes is the common practice, therefore, probabilities of spreading venereal diseases such as trichomoniasis, vibriosis and other specific reproductive tract infection cannot be excluded. Moreover, factors such as dystocia, retained placenta, metabolic disorders and age of the ewes, play a role in postpartum uterine infections as reported in the large ruminants (Studer and Morrow, 1978 and Roberts, 1986). Most of the ewes that were slaughtered were actually culled animals with breeding problems. The results documents well the finding of high incidence of genital tract infections in the Egyptian ewes. The data also documents the prevalence of high incidence of uterine abnormalities including hydro/mucometra, endometritis and pyometra in ewes with abnormal ovarian conditions than in those with normal ovaries. Therefore these results indicate a direct strong association between uterine and ovarian abnormalities in the Egyptian ewes.

The affected ewes were 112 from total 300 examined representing $37.33 \%$ of the total tracts examined. Concerning the incidence of lesions in the present study it was found to be higher than $(16.6 \%)$ recorded by Bahgat et al. (1993), 9.4\% by Alosta et al. (1998), 6.57\% by Smith et al. (1998), 29.09\% by Dokhan (2000) but lower than $44.12 \%$ recorded by Dzhurova et al. (1985). The difference in the incidence can be attributed to different sheep breeds, breeding systems, management systems, localities and environment. 
Presence of the same lesions in different segments of the reproductive tract my indicate either extension of infection in case of infectious lesions or hormonal mediated effect.

The uterus was the most frequently affected segment of the genital tract of ewes $(27.3 \%)$ followed by ovaries (21.3\%), fallopian tubes $(11 \%)$ and cervix $(7.3 \%)$.

The present investigation revealed ovarian affection with incidences of $15.7 \%$; which is higher than that reported by Smith et al. (1998 and 1999). Concerning the pathogenesis of Follicular atrasia, it could be either initiated by decrease of FSH as it has been prevented by the administration of pregnant mare serum gonadotrophin in rats (Hirshfield, 1986). Its association with uterine lesions lead to suggestion that cystic ovary together with follicular atresia could be attributed to the damage caused by endotoxin in the infected uterus which stimulates cortisol secretion by adrenal gland leading to suppress of ovulation surge of LH hormone resulting in atresia and cystic follicle (Acland (2001).

Regarding the Detailed correlation of the of ovarian cysts, cystic follicles are those with a diameter greater than $10 \mathrm{~mm}$ a criterion based on the conclusion of Grant (1934) and Alosta et al. (1998). As most of the ewes were out of breeding, the size of the follicle was not the only criteria for identifying follicular cyst but also degeneration of the ovum and granulosa cells and increase in theca layer were considered. The follicular cysts in ewes could be attributed to endocrine imbalance a matter which have been augometed by hormonal analysis by Alosta et al. (1998) who reported high progesterone level in these follicles with low estradiol level compared with low progesteine and higher estradiol in large follicle and normal graffian follicles. The anovulatory follicular cyst could be related to inadequate or delayed release of LH making the animal anoestrus. McEntee (1990) and Aldshash and David (1977c). 
Cystic and Persistent corpora corpora lutea were seen in 4 cases, in one case was associated with pyometra. Cystic corpus luteum develops as a result of premature closure of the ruptured site with formation of central cavity in the developing corpus luteum McEntee (1990). It were associated usually with pathological affection of the uterus which lead to absence of luteolytic factors such as PGF2 $\alpha$ from the damaged uterus. Such association has been emphasased by McEntee (1990) and Acland (2001).

Ovariobursal adhesions can arise from the ovulation sites following organization of the ovulation fluid and haemorrhage which adhere to the adjacent part of the bursa. While complete ovariobursal adhesion in ewes was concurrently occuring with perioophoritis, salpingitis, hydrosalpinx, endometritis and pyometra. Its rule as a possible cause of infertility was discussed by Smith et al. (1999).

Salpingitis was diagnosed in 9 cases representing 3\% of all examined ewes. It has been described at lower incidence by Alosta et al. (1998), KaradaŞ and Timurkaan (1998) and Dokhan (2000) On the other hand Sokkar and Kubba (1980) and Acland (2001) described similar findings with higher incidences. They stated that Fallopian tube adhesion was one of the most common lesion representing $4.3 \%$ of the total tracts examined and was usually associated with perioophoritis, hydrosalpinx and pyosalpinx and appeared as massive proliferation of connective tissue.

Hydrosalpinx was recorded in $1 \%$ of the examined tracts. It can arise in several ways, as a sequel to salpingits, as a result of external pressure, or possibly as a result of congenital abnormalities (Smith. 1999). It could also occurs in conjunction with hyperplasia of the epithelium of the fallopian tube in response to chronically higher estrogen concentration as reported by King, (1978) in Mice. 
Cystic changes in the fallopian tube was seen $1.66 \%$ of the total examined tracts. It was usually associated with cystic ovarian diseases and chronic salpingitis. Similar changes were detected in bovine by Kessy and Neakes (1985) in bovine. It could be caused by estrogen or oxytocin stimulation or as a sequallae to chronic salpingitis.

Pyosalpinx was found in $0.66 \%$ of the total tracts examined. It was usually associated with pyometra indicating ascending infection from the uterus.

Fallopian tube Occlusion was recorded in $0.66 \%$. It was usually related to persistent or chronic infection such as pyometra or macerated fetus resulting in salpingitis with subsequent occlusion or could be associated with death of migrating fertilized ova or morula undergoing necrosis and calcification.

Squamous metaplasia of the fallopian tube was recorded in one case which was associated with pyometra. Sokker and Kubba (1980) reported squamous metaplasia in an ewe in association with chronic salpingitis while Palludan (1966) referred it to Vitamin A deficiency in swine and Chang et al. (1979) attributed it in the same species to zeralenone mycotoxicosis in which the all tract underwent squamous metaplasia.

Pachysalpinx was recorded in one case and macroscopically it was characterized by enlargement of the whole length of the fallopian tube resulting in Kinking and distortion of the normal shape of the fallopian tube. similar finding was observed by Kessy and Neakes (1985).

Collectively the present study revealed that acquired fallopian tube abnormality represented $13.3 \%$ of the total tracts examined which denote that fallopian tube abnormalities can be considered as one of the main causes of infertility in female ewes. 
The inflammatory lesions of the uterus showed the second highest incidence of the uterine abnormalities present in $6 \%$ of the total examined tracts. Similar high incidence has been recorded in earlier studies in ewes (Bahgat et al., 1993 and Dokhan, 2000). and considered as the most common cause of infertility in cattle and buffaloes (Kennedy and Miller (1993). In the present study the endometritis was classified upon the microscopical examination in accordance with what reported by KaradaŞ and Timurkaan (1999), Dokhan (2000) and Mostafa (2004) into three types, catarrhal endometritis in $4.3 \%$, purulent endometritis in $3 \%$ and granulomatous endometritis in $1 \%$ of the cases. Granulomatous endometritis recorded in $1 \%$ of the cases with a features similar to tuberculous granuloma showing presence of acid and alcohol fast bacilli after Zheil Neelson stain. Granulomatous lesions of the ovary or the uterus usually indicating infection through blood.

Cystic endometrial hyperplasia was the most common uterine lesion. It was detected in $9 \%$ of the cases. It was in some cases associated with cystic ovarian disease in which the glandular changes could be attributed to the effect of hormones secreted by active cysts (Kennedy and Miller, 1993). Iit can also be related to feeding on estrogenic plants (Cantero et al., 1996). Regarding the higher incidence reported herein, in comparison to the bovine it is in harmony with the report of Acland (2001). He arranged different animals according to the incidence of endometrial cysts, the ewe was the first followed by bitch, cow, cat and finally sow. In our opinion this because sheep fed mainly by grassing with increasing chance of feeding on estroging plants than any other animals.

Uterine adhesions were recorded in $1 \%$ of examined tracts and they were usually related to certain pathological conditions of the uterus as perimetritis and parametritis or associated with both ovarian and uterine 
infection such as pyometra and oopheritis. This also observed by Smith et al., 1999 who found 29 cases of perimetritis and metritis associated with intestinal adhesion or adhesion with abdominal wall.

Dead feti were found in 5 cases representing $1.66 \%$ of the total examined tracts. Three cases of them showed macerated feti while the other two cases were intact indicating mummified feti. Intrauterine dead feti were also recorded by Nair and Raja (1972), Elwishy et al. (1974), Hailat et al. (1997), Smith et al. (1999) and Dokhan (2000). The changes occurred in the endometrium and the uterine wall were related to toxic and irritant effect of the dead fetus.

Adenomyosis was recorded in $0.66 \%$ of the cases, associated with either chronic endometritis or glandular hyperplasia. Similar findings were recorded by Aly (1990), and Dokhan (2000) who mentioned that the hyperplastic glands tightly packed within the connective tissue tended to extend deep within and in-between the muscle bundles.

Cervicitis was the most common lesion of the cervix representing $5 \%$ of the total examined tracts. Dokhan (2000) found it in $6.7 \%$ while KaradaŞ and Timurkaan (1999) reported it in $0.68 \%$. Most of the cases of cervicitis were accompanied with endometritis, when not it could be an extension from vaginitis (McEntee, 1990 and Dokhan, 2000). Since clinical diagnosis was not possible in the present study, cervicitis was classified microscopically into acute catarrhal or acute suppurtive cervicitis depending mainly on the type of inflammatory cell infiltration and acute and chronic according to presence of features of chronicity as fibroplasia. 
Squamous metaplasia of the cervix was recorded in 2 cases associated with pyometra in one case and mummified fetus in the other while Adams(1976)and McEntee(1990)attributed squamous metaplasia to toxicity with chlorinated naphthalene or estrogenic plants.

Cervical hyperplasia was recorded in 4 cases usually associated with cystic ovary and endometritis.

Well differentiated squamous cell carcinoma was recorded in 3 cases $(1 \%)$ as far as available literature no squamous cell carcinoma in ovine uterine cervix was recorded, but adenocarcinoma was described by Dokhan (2000).

\section{CONCLUSION}

The present study draw attention to different lesion in ovine reproductive tract which can be possible cause of infertility. It showed direct relationship between ovarian and uterine lesions. The results demonstrated that cystic endometrium hyperplasia was the most common uterine lesions suggesting feeding of the animals on estrogen containing plants. It also revealed that many lesions were infectious and of complicated nature giving indication about bad managemental, hyagenic, nutritional and therapeutic interferences.

Therefore we conclude that these results indicate that acquired genital tract abnormalities in Egyptian ewes is of complex combination between infectious, managemental and nutritional causes, and these results may help to provide information on the prevalence of ovine reproductive diseases or diseases conciliations in Egypt. Accordingly, the ovine practitioners as will as veterinarians will have added knowledge for appropriate preventive measures and therapeutic interference to be taken.

NB. A part of a thesis under the supervision of Prof. Dr. A. R. Khater

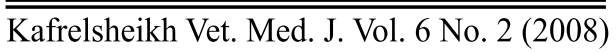




\section{REFERENCES}

- Acland, H.M. (2001). Female reproductive system in: Thompson's special Veterinary Pathology. Eds. McGavin, M.D.; Carlton, W.W. and Zchory, J.F. 3rd Ed., Chapter 12, pp. 601-634. Mosby, A. Harcourt Health Sciences Company, St. Louis, London, Philadelphia, Sydney.

- Adams, N.R. (1975). A pathological and bacteriological abattoir survey of the reproductive tracts of Merino ewes in Western Australia. Aust. Vet. J., 51: 351-354.

- Al-Dahash, S. Y. and David, J. S. E. (1977). The incidence of ovarian activity, pregnancy and bovine genital abnormalities shown by abattoir survey. Vet. Rec. 101: 269-299.

- Alosta, R.A.; Vaughan L. and Collins, J.D. (1998). An abattoir survey of ovine reproductive tracts in Ireland. Theriogenology, 50(3): 457-464.

- Aly, S.E. (1990). Pathological studies on the relation between the ovarian and uterine affections in ewes at Ismailia Province. M.V.Sc. Thesis, Pathology, Faculty of Veterinary Medicine, Suez Canal University.

- Bahgat, A.M.; Shalaby, A.S.; Abou El-Fetouh, M.S. and Aly, S.E. (1993). Pathological studies on ovarian and uterine lesions in ewes. Egypt. J. Cop. Path. and Clin. Path., 69(2): 247-260.

- Bancroft, J.D. , and Stevens, A. (1996). Theory and practice of Histological techniques . Fourth Edition. 
- Cantero, A.; Sancha, J.L.; Flaves, J.M.; Rodriguez, A. and Gonzalez, T. (1996). Histological changes in the reproductive organs of Manchego ewe grazing on lucense. J. Vet. Med., 43(A): 325-330.

- Chang, K.H, Kurtz, J. and Miracha, C. J. (1979). Effect of the mycotoxin zeralenone on swine reproduction. Am. Vet. Res. 40: 1260-1267.

- Dokhan, K.Z. (2000). Studies on some pathological alterations in the ovine female genitalia. Ph.D. Thesis, Pathology. Cairo University.

- Dzhurova, I.; Marinov, M.; Marinov, P. and Tashev, S. (1985). Morphological changes in the genitalia of culled sheep. Vet. Med. Nauki, 22(5): 43-52.

- Elwishy, A.B.; Atalla, O.A. and Elsawaf, S.A. (1974). Some aspects of reproduction in fat-tailed sheep in subtropics: III. Pathological conditions of the genital tract. Vet. Med. J., 20: 111-123.

- Esawy, S. A. (2007). Personal contact.

- Grant, F. (1934). Studies on the physiology of reproduction in the ewe. Part III. Gross changes in the ovaries. Trans. R. Soc. Edinburgh, 58: $36-47$.

- Hailat, N.Q.; Lafi, S.Q.; Darraji, A.; Al-Ani, F. and Fathalla, M. (1997). Ovine fetal maceration small ruminant Research, 25(1): 89-91.

- Hirshfield, N.R. (1986). Effect of a low dose pregnant mares serum gonadotrophin on follicular recruitment and strasia in cycling rats. Biology of Reproduction, 35: 113-118. 
- KaradaŞ.E and Timurkaan,N.(1998).Pathomorphologic investigation on the genital system of ewes I ovarium and oviduct. Tr. J. Vet. Amin. Sci., 23: 557- 565.

- KaradaŞ.E and Timurkaan,N.(1999).Pathomorphologic investigation on the genital system of ewes II uterus,cervix and vagina. Tr. J. Vet. Amin. Sci, 25: 27-37.

- Kennedy, P.C. and Miller, R.B. (1993). The female genital system. In: Pathology of Domestic Animals. Eds. Jubb, K.V.F.; Kennedy, P.C. and Palmer, N. 4th Ed.; Vol. 3, pp. 349-470, Academic Press, Harcourt Brace, San Diego, New York, Boston, London, Sydney, Tokyo.

- Kessy, B.M. and Neakes, D.E. (1985). Uterine tube abnormalities as a cause of bovine infertility. Vet. Rec. 117:122-124.

- King, N.V. (1978). The reproductive tract. In Pathology of Domestic animals. Eds: Jubb., N.V.F.; Kennedy, P.C. and Palmer, N. San Diego, Academic Press. PP. 349-470.

- McEntee, K. (1990). Reproductive Pathology of Domestic Mammals. Academic Press, New York, Boston, London, Sydney Tokyo, Toronto.

- Mostafa, A.H.S. (2004). Pathological studies on pre and postpartum disease in sheep and goat. Ph.D., thesis Pathology, Cairo University.

- Nair, K.P. and Raja, C.K.S.V. (1972). Pathological conditions in the genital organs of Goats. Kaerala. J. Vet. Sci., 3: 109-119. 
- Palludan, B. (1966). A-vitaminosis in swine. A study on the importance of vitamin A for swine reproduction. Munk-Sgaard, Copenhagen. Cited In Reproductive Pathology of Domestic Mammals Eds. McEntee. Academic Press, New York, Boston, London, Sydney, Tokyo.

- Roberts, S. J. (1986). Injuries and diseases of the puerperal period. In: Veterinary obstetrics and genital diseases. (Theriogenology). 3rd ed. Woodstock, Vermont: Published by the author, pp.353-396 and hereditary or congenital defects of the reproductive tract. pp 520-533.

- Smith, K.C.; Long, S.E. and Parkinson, T.J. (1998). Abattoir survey of congenital reproductive abnormalities in ewes. Vet. Rec., 143: 679685.

- Smith, K.C.; Parkinson, T.J. and Long, S.E. (1999). Abattoir survey of acquired reproductive abnormalities in ewes. Vet. Rec. 144: 491496.

- Sokkar, S.M.and Kubba, M.A. (1980). Pathological studies on the fallopian tubes of ewes.zentralblatt fur veterinarmedizin, Reihe A 27: 118-122.

- Studer, E. and Morrow, D. A (1978): Postpartum uterine evaluation of bovine reproductive potential: Comparison of findings from genital tract examination per rectum, uterine culture and endometrial biopsy. J. Am. Vet. Med. Ass. 172(4): 489-494,. 